\title{
Temporary alterations to postpartum milking frequency affect whole-lactation milk production and the energy status of pasture-grazed dairy cows
}

\author{
C. V. C. Phyn, ${ }^{* 1}$ J. K. Kay, ${ }^{*}$ A. G. Rius, $†$ S. R. Morgan, ${ }^{*}$ C. G. Roach, ${ }^{*}$ T. M. Grala, $\ddagger$ and J. R. Roche ${ }^{*}$ \\ *DairyNZ, Private Bag 3221, Hamilton 3240, New Zealand \\ †Department of Animal Science, The University of Tennessee, Knoxville 37996 \\ †DairyNZ, c/o University of Auckland, 3A Symonds St, Auckland 1010, New Zealand
}

\begin{abstract}
This study investigated the immediate and long-term effects of temporary alterations to postpartum milking frequency (MF) on milk production, body condition score (BCS), and indicators of energy status in pasturegrazed cows supplemented with concentrates. Multiparous Holstein-Friesian cows $(\mathrm{n}=150)$ were randomly assigned to 1 of 5 groups at calving: milked twice daily $(2 \times)$ throughout lactation (control), or milked either once daily $(1 \times)$ or 3 times daily $(3 \times)$ for 3 or $6 \mathrm{wk}$ immediately postpartum, and then $2 \times$ for the remainder of lactation. During wk 1 to 3 postpartum, cows milked $1 \times$ produced $15 \%$ less milk and $17 \%$ less energy-corrected milk (ECM) than cows milked $2 \times$. This immediate production loss increased to $20 \%$ less milk and $22 \%$ less ECM during wk 4 to 6 postpartum for cows that remained on $1 \times$ milking; these animals also produced less than $1 \times$ cows switched to $2 \times$ milking after 3 wk. During wk 8 to 32 , when all cows were milked $2 \times$, those previously milked $1 \times$ had sustained reductions in milk $(-6 \%)$ and ECM $(-8 \%)$ yields, which were not affected by the duration of reduced postpartum MF. In contrast, cows milked $3 \times$ postpartum had $7 \%$ greater milk yields during wk 1 to 6 compared with $2 \times$ controls, irrespective of the duration of increased MF. Milk yields also remained numerically greater $(+5 \%)$ during wk 8 to 32 in cows previously milked $3 \times$. Nevertheless, yields of ECM were not increased by $3 \times$ milking, because of lower milk fat and protein contents that persisted for the rest of lactation. In addition, indicators of cow energy status reflected an increasing state of negative energy balance with increasing MF. Cows milked $1 \times$ postpartum had greater plasma glucose and lower plasma nonesterified fatty acid concentrations during the reduced MF, and plasma glucose remained lower for 2 wk after cows had switched to $2 \times$ milking. Moreover, BCS was improved relative to $2 \times$ controls from wk 5
\end{abstract}

Received December 16, 2013.

Accepted July 22, 2014.

${ }^{1}$ Corresponding author: claire.phyn@dairynz.co.nz to 6 . In contrast, cows milked $3 \times$ had lower plasma glucose concentrations, greater plasma nonesterified fatty acid concentrations, and greater BCS loss during wk 1 to 3 ; however, greater body fat mobilization was not sustained, indicating that additional energy supplements may be required to achieve better milk production responses. In conclusion, temporary $1 \times$ milking had lactation-long negative effects on milk and milk component yields but improved cow energy status and BCS, whereas temporary $3 \times$ milking immediately increased milk yield but did not improve milk fat and protein yields in pasture-grazed cows.

Key words: milking frequency, early lactation, dairy cow, energy status

\section{INTRODUCTION}

Substantial evidence exists that the milking frequency (MF) of dairy cows can be strategically manipulated to improve milk production efficiency. Many studies (e.g., Bar-Peled et al., 1995; Hale et al., 2003; Dahl et al., 2004) have demonstrated that a short period of frequent milking ( 3 or more times daily) during early lactation stimulated a persistent increase in milk production for the remainder of lactation. Furthermore, as little as 14 d of increased MF during the first 3 wk postpartum generated a long-lasting increase in milk production in a half-udder experiment (Wall and McFadden, 2007). These results indicate that a short-term increase in postpartum MF could be used by dairy producers to improve whole-lactation yields.

Although the majority of research has been conducted using high-yielding cows fed TMR (Bar-Peled et al., 1995; Hale et al., 2003; Dahl et al., 2004), 3-times-daily $(\mathbf{3} \times)$ milking during early lactation may also result in a sustained increase in milk production in cows grazing pasture, provided nutrition is not limiting (Phillips et al., 1980). Kolver and Muller (1998) identified DMI as the major factor limiting milk production in grazing cows; however, the prudent use of concentrate supplements (Roche et al., 2006, 2013) might facilitate the increase in DMI needed to capitalize on this putative benefit of short-term $3 \times$ milking. 
Conversely, decreasing MF to once daily $(\mathbf{1} \times)$ during early lactation is of interest to dairy producers seeking to capture labor and lifestyle benefits (Stelwagen et al., 2013); this is particularly true in pasture-based systems, where seasonal calving causes a rapid influx of fresh cows, putting pressure on feed resources, staff, and cow management processes. The disadvantage of milking cows $1 \times$ is that it decreases milk production (Davis et al., 1999; Rémond and Pomiès, 2005; Stelwagen et al., 2013), although evidence exists of a consequent improvement in energy balance (McNamara et al., 2008; Loiselle et al., 2009; Schlamberger et al., 2010). Furthermore, $1 \times$ milking for a short period $(6$ wk or less) after calving reduces subsequent milk production in housed dairy cows (Rémond et al., 1999; McNamara et al., 2008; Schlamberger et al., 2010), consistent with the positive association between increased MF and production (Wall and McFadden, 2008; 2012). The duration of $1 \times$ milking that minimizes the negative carryover effect on milk production is not clear. Loiselle et al. (2009) reported that milking $1 \times$ for 1 wk postpartum caused a long-term reduction in milk yield, but in other studies (Rémond et al., 1999; Rémond et al., 2002) no significant carryover loss occurred following 3 wk of $1 \times$ milking. Characterization of this duration effect is required to develop strategies that maximize the benefits of $1 \times$ milking (e.g., improved energy balance and labor productivity), while minimizing the loss of milk production and revenue.

This study tested the hypothesis that temporarily decreasing the postpartum MF of grazing dairy cows would decrease immediate and subsequent milk production but improve energy status, whereas increasing MF would have the opposite effect. Furthermore, it was hypothesized that these effects would depend upon the duration of altered postpartum MF. Therefore, the immediate and long-term effects of altered MF $(1 \times$ or $3 \times$ milking) for 3 or 6 wk postpartum on milk production, plasma hormones and metabolites, BCS, BW, and fertility were determined in grazing cows supplemented with concentrates.

\section{MATERIALS AND METHODS}

This study was conducted at the DairyNZ Lye Farm (Hamilton, New Zealand; $37^{\circ} 46^{\prime} \mathrm{S}, 175^{\circ} 18^{\prime} \mathrm{S}$ ) from June 2009 to May 2010. All procedures had prior approval (RAEC 11812) of the Ruakura Animal Ethics Committee (Hamilton, New Zealand).

\section{Experimental Design and Treatments}

One hundred fifty multiparous Holstein-Friesian (n $=106)$ and Holstein-Friesian $\times$ Jersey crossbred $(\mathrm{n}$
$=44)$ cows were randomly assigned to 1 of 5 treatments at calving (mean \pm SD; July 15, $2009 \pm 10.6$ d). Treatments were milked twice daily $(\mathbf{2} \times)$ for the entire lactation (control; $\mathrm{n}=30$ cows), milked $1 \times$ for either 3 or 6 wk immediately postpartum and $2 \times$ thereafter ( $\mathrm{n}=30$ cows each), or milked $3 \times$ for either 3 or 6 wk immediately postpartum and $2 \times$ thereafter $(\mathrm{n}=28$ and 32 cows, respectively). Daily milking times were $0700 \mathrm{~h}$ for $1 \times$ milking (24-h interval), 0700 and $1500 \mathrm{~h}$ for $2 \times$ milking (16/8-h interval), and 0700,1500 , and $2200 \mathrm{~h}$ for $3 \times$ milking $(9 / 8 / 7$-h interval). All cows were milked $2 \times$ after wk 6 postpartum and were individually dried-off when milk yields dropped below $5 \mathrm{~kg}$ milk/d for 2 consecutive wk, with a final dry-off date of May 14, 2010.

\section{Grazing Management and Supplementary Feeding}

All cows were offered a generous allowance of perennial ryegrass/white clover pasture ( $\sim 30$ to $45 \mathrm{~kg} \mathrm{DM} /$ cow per day to ground level) throughout the study. From 2 wk before their predicted calving date, cows were also offered $2 \mathrm{~kg}$ of DM/cow per day of a pelleted maize/barley/molasses-based concentrate in one feed at $0900 \mathrm{~h}$. Following calving, cows were individually offered $4 \mathrm{~kg}$ of $\mathrm{DM} / \mathrm{d}$ of the same concentrate during the a.m. milking until November 1, 2009 (i.e., 109 DIM), and $2 \mathrm{~kg}$ of DM/d thereafter, until November 24, 2009.

Cows milked $1 \times, 2 \times$, or $3 \times$ were grazed in the same paddock (defined grazing area) and separated by double-stranded electric fences so that they could be drafted independently to the farm dairy for milking. Cows in $1 \times$ or $3 \times$ milking treatments were moved into the $2 \times$ milking herd after completing their 3 - or 6 -wk period of decreased or increased postpartum MF, respectively, and grazed together for the remainder of the experiment.

Cows were rotationally grazed and had access to a fresh allocation of pasture daily as described by Roche et al. (2002). Briefly, cows had access to 50 paddocks of $1 \mathrm{ha} /$ paddock and these paddocks were grazed in a rotational order. As a result, cows only returned to the same grazing area when a minimum of 2 leaves had regrown on the majority $(>66 \%)$ of perennial ryegrass (Lolium perenne L.) tillers.

Pre- and postgrazing pasture mass was estimated on $3 \mathrm{~d}$ each week from June to November 2009 (i.e., from 1 mo before the planned start of calving to mid lactation) and $1 \mathrm{~d}$ each week thereafter, using a Rising Plate Meter installed with an electronic counter (Farmworks Ltd., Palmerston North, New Zealand) calibrated as described by Roche et al. (2005). Briefly, pasture samples ( $\mathrm{n}=15-20)$ were cut to ground level within rectangular quadrats $\left(0.125 \mathrm{~m}^{2}\right)$ placed randomly within pasture 
Table 1. Chemical composition of pasture as measured by near-infrared reflective spectroscopy ${ }^{1}$

\begin{tabular}{lcccc}
\hline & \multicolumn{3}{c}{ Month } \\
\cline { 2 - 5 } Variable $^{2}$ & July-August & September-November & December-February & March-April \\
\hline DM, \% & $17.0 \pm 3.1$ & $15.1 \pm 2.5$ & $17.8 \pm 1.9$ & $19.5 \pm 3.6$ \\
ME, MJ/kg of DM & $12.2 \pm 0.4$ & $12.3 \pm 0.4$ & $11.4 \pm 0.6$ & $11.3 \pm 0.8$ \\
ADF, \% of DM & $22.4 \pm 1.2$ & $24.0 \pm 1.9$ & $25.4 \pm 0.4$ & $23.6 \pm 2.4$ \\
Ash, \% of DM & $10.1 \pm 0.8$ & $10.2 \pm 0.8$ & $9.6 \pm 0.5$ & $10.4 \pm 0.1$ \\
CP, \% of DM & $21.3 \pm 3.7$ & $21.6 \pm 2.3$ & $19.5 \pm 1.7$ & $21.7 \pm 2.7$ \\
Lipid, \% of DM & $3.7 \pm 0.3$ & $3.6 \pm 0.2$ & $48.6 \pm 0.1$ & $3.0 \pm 0.6$ \\
NDF, \% of DM & $43.8 \pm 1.7$ & $44.1 \pm 3.3$ & $77.6 \pm 5.0$ & $49.0 \pm 5.1$ \\
OMD, \% of OM & $82.8 \pm 4.2$ & $85.1 \pm 2.3$ & $8.0 \pm 2.2$ & $9.1 \pm 4.9$ \\
SSS, \% of DM & $8.4 \pm 1.6$ & $10.7 \pm 4.2$ & & \\
\hline
\end{tabular}

${ }^{1}$ Means \pm SD are presented.

${ }^{2} \mathrm{OMD}=\mathrm{OM}$ digestibility; SSS $=$ soluble sugars and starch

allocations to be grazed the following day, and for residual DM, those grazed during the previous $24 \mathrm{~h}$. Pasture samples were washed to remove soil contamination and dried at $95^{\circ} \mathrm{C}$ to constant weight (approximately $72 \mathrm{~h}$ ). Resultant DM yields (g) $/ 0.125 \mathrm{~m}^{2}$ were multiplied by 0.08 to give tonnes of DM yield per hectare pre- and postgrazing. Compressed pasture heights were measured inside each $0.125-\mathrm{m}^{2}$ quadrat before cutting, and data used to develop a regression equation relating pasture height to pasture mass.

High postgrazing residuals (targeted 1,800 kg of DM/ ha measured to ground level in late winter, spring, and autumn, and 2,200 to $2,400 \mathrm{~kg}$ of $\mathrm{DM} / \mathrm{ha}$ in summer) were used to ensure that DMI was not limited by pasture allocation. Pasture quality was maintained throughout the season, despite the high grazing residuals, through strategic use of mechanical cutting of the high residuals or grazing the high residuals with a nontreatment herd following the treatment animals. Pasture silage was offered to maintain pasture residuals when pasture availability was limited: $3.6 \mathrm{~kg}$ of $\mathrm{DM} / \mathrm{cow}$ per day for $40 \mathrm{~d}$ during July and August 2009, and $5.0 \mathrm{~kg}$ of DM/ cow per day for $21 \mathrm{~d}$ in April 2010.

\section{Feed Sampling and Measurements}

Representative samples of pasture were collected weekly by hand clipping 8 quadrats $\left(50 \mathrm{~cm}^{2}\right)$ to estimated grazing height across a diagonal transect of the area to be grazed. Samples of concentrate and pasture silage were collected weekly when offered to cows. Duplicate samples were oven dried at either $95^{\circ} \mathrm{C}$ for $72 \mathrm{~h}$ to determine DM content or at $65^{\circ} \mathrm{C}$ for $48 \mathrm{~h}$ for subsequent analysis of nutrient composition. The latter were bulked every second week between July and November 2009, and then once every month thereafter to April 2010. Bulked samples were then ground to pass through a $0.5-\mathrm{mm}$ sieve, and analyzed for chemical composition by near-infrared reflective spectroscopy (FeedTech,
Palmerston North, New Zealand). The composition of the pasture is presented in Table 1 . The average $( \pm \mathrm{SD})$ composition of the concentrate fed was $89.6 \pm 1.1 \%$ $\mathrm{DM}, 4.4 \pm 0.8 \%$ of DM ADF, $2.5 \pm 0.6 \%$ of DM ash, $10.7 \pm 0.6 \%$ of DM CP, $4.1 \pm 1.7 \%$ of DM lipid, 18.8 $\pm 4.3 \%$ of DM NDF, $63.2 \pm 2.6 \%$ of DM soluble sugars and starch, and $>13 \mathrm{MJ}$ of ME/kg of DM. The average composition of the pasture silage fed was $24.8 \pm 2.8 \%$ $\mathrm{DM}, 32.8 \pm 0.6 \%$ of $\mathrm{DM} \mathrm{ADF}, 11.4 \pm 0.8 \%$ of $\mathrm{DM}$ ash, $18.1 \pm 1.6 \%$ of DM CP, $8.9 \pm 0.4 \%$ of DM lipid, $51.9 \pm 1.6 \%$ of DM NDF, $3.2 \pm 0.0 \%$ of DM soluble sugars and starch, $>85 \%$ in vitro digestibility, $66.9 \pm$ $1.5 \mathrm{mg} / 100 \mathrm{~g}$ of DM ammonia nitrogen, and $>13 \mathrm{MJ}$ of $\mathrm{ME} / \mathrm{kg}$ of DM.

In addition, botanical composition of pasture offered was evaluated once every second week between July 2009 and February 2010, and then once every month thereafter to April 2010; on average $( \pm \mathrm{SD})$, pastures consisted of $67.5 \pm 15.8 \%$ of DM perennial ryegrass, 6.1 $\pm 7.7 \%$ of DM annual ryegrass, $4.1 \pm 5.2 \%$ of DM other grasses, $8.6 \pm 6.9 \%$ of DM white clover, $8.4 \pm 9.0 \%$ of DM weeds, and $5.4 \pm 4.7 \%$ of DM dead material.

\section{Animal Measurements}

Milk. Individual milk yields were recorded at each milking (Westfalia Surge Metatron Milk Meter; GEA Farm Technologies, Cambridge, New Zealand). Milk fat, $\mathrm{CP}$, and lactose concentrations in milk were determined by MilkoScan milk analyzer (Foss Electric A/S, Hillerød, Denmark) on individual aliquot samples collected on $1 \mathrm{~d}$ each week $(1 \times$, a.m. milking; $2 \times$, p.m. and a.m. milkings; $3 \times$, p.m. and additional p.m. and a.m. milkings). Milk component data were verified by reference techniques for a subset of milk samples [milk fat by the Röse-Gottlieb method (IDF, 1987); CP by the Kjeldahl technique (Barbano et al., 1991); lactose by the chloramine-T method (Amin et al., 1982)]. Energy-corrected milk was calculated as kilograms of 
ECM per cow per day $=$ kilograms of milk per day $\times$ $[(383 \times$ fat $\%)+(242 \times$ protein $\%)+783.2)] / 3,140$ (Tyrrell and Reid, 1965). Milk $\mathrm{NE}_{\mathrm{L}}$ was calculated as megajoules per kilogram of milk $=4.186 \mathrm{MJ} /$ Mcal $\times$ $[(0.0929 \times$ fat $\%)+(0.0547 \times \mathrm{CP} \%)+(0.0395 \times$ lactose \%)] (NRC, 2001). Milk SCC was determined weekly using a Fossomatic automated cell counter (Foss Electric A/S).

$\boldsymbol{B} \boldsymbol{W}$ and $\boldsymbol{B C S}$. Body weight and BCS were determined weekly until September and biweekly thereafter. Body condition score was assessed on a 10-point scale, where 1 is emaciated and 10 is obese (Roche et al., 2004). These scores can be converted to the 5 -point scale of Wildman et al. (1982) using the regression equation generated by Roche et al. (2004; 5 -point BCS $=1.5+0.32 \times 10$-point BCS).

\section{Blood Sampling and Analysis}

Blood was sampled on the same $1 \mathrm{~d}$ each wh for the first 12 wk postpartum. A 10-mL evacuated blood tube (containing $140 \mathrm{IU}$ of sodium heparin; Becton Dickinson, Franklin Lakes, NJ) was collected from each cow by coccygeal venipuncture immediately before the morning milking (approximately $0700 \mathrm{~h}$ ). Samples were placed on ice and then centrifuged at 1,120 $\times g$ for 12 min at $4^{\circ} \mathrm{C}$. Plasma was harvested and stored at $-20^{\circ} \mathrm{C}$ until analysis.

Analyses of metabolites and liver enzymes were performed on a Modular P800 analyzer (F. Hoffmann-La Roche Ltd., Basel, Switzerland) at $37^{\circ} \mathrm{C}$ by Gribbles Veterinary Pathology Ltd. (Hamilton, New Zealand). Nonesterified FA were measured $(\mathrm{mmol} / \mathrm{L})$ by the acyl Co-A synthetase, acyl-CoA oxidase (ACS-ACOD) colorimetric method using the NEFA C Kit from Wako (Osaka, Japan), and glucose was determined (mmol/L) photometrically by the glucose oxidase/4-aminophenazone/phenol (GOD-PAP) method. Liver enzyme glutamate dehydrogenase (GDH) concentration (IU/L) was determined by a UV test based upon the NADHdependent formation of glutamate, and aspartate aminotransferase (AST) concentration (IU/L) was determined photometrically using the oxaloacetate/malate/ NAD method. The inter- and intraassay coefficients of variation were $<2 \%$ for all assays, except GDH, which had an interassay coefficient of variation of $5 \%$.

Growth hormone (GH: ng/mL; Downing et al., 1995), IGF-I (ng/mL; Gluckman et al., 1983), and insulin $(\mu \mathrm{U} / \mathrm{mL}$; Hales and Randle, 1963) were measured in duplicate by double-antibody RIA by the University of Western Australia (Perth, Australia) with inter- and intraassay coefficients of variation $<6 \%$. The assay methods were previously validated for bovine plasma samples as described by Chagas et al. (2007). The assay detection limits were $0.06 \mathrm{ng}$ of $\mathrm{GH} / \mathrm{mL}, 1 \mathrm{ng}$ pf IGF-I/ $\mathrm{mL}$, and $0.89 \mu \mathrm{U}$ of insulin $/ \mathrm{mL}$. Analyses of plasma progesterone concentrations were determined using a Siemens coat-a-count RIA kit (Siemens, PA).

\section{Breeding Management}

Postpartum anestrous interval (PPAI) was calculated for a subset of cows ( $\mathrm{n}=18 /$ treatment) using the difference between calving date and the first blood sampling date that plasma progesterone exceeded 1 $\mathrm{ng} / \mathrm{mL}$. Visual observations of estrous activity were recorded daily from calving. Cows were bred to spontaneous estrus after a fixed calendar date associated with seasonal milk-production systems (planned start of mating: September 22, 2009); AI was used for 6 wk and followed by natural mating for 4 wk. Pregnancy diagnosis was conducted at 72 and $113 \mathrm{~d}$ after the planned start of breeding to confirm conception rates and pregnancy rates. Submission, conception, and pregnancy rates were measured for each treatment group.

\section{Statistical Analyses}

One cow in the "milked $1 \times$ for 6 wk" treatment was removed from the experiment on September 25, 2009 (70 DIM), for health reasons not associated with treatment; her data were removed from all analyses. A cow from the "milked $3 \times$ for $3 \mathrm{wk}$ " treatment was removed for health reasons not associated with treatment on January 20, 2010 (180 DIM); data were included up to this time point, but excluded from analysis of total milk production.

Repeated measurements through time were modeled for milk production and composition, BW and BCS, and plasma hormone, metabolite, and liver enzyme data using cubic splines within the linear mixed-model framework in GenStat software (version 13.2; VSN International Ltd., Hemel Hempstead, UK), as described by Verbyla et al. (1999). Milking frequency $(1 \times, 2 \times$, or $3 \times$ ), duration ( 3 or $6 \mathrm{wk}$ ), the linear trend of time, and their interaction were included as fixed effects, and cow, the linear trend of time within cow, spline, and the interaction of MF and duration with spline were included as random effects. As treatment (MF or duration, or both) by time interactions $(P<0.05)$ were present, data were also analyzed at each week and during treatment and carryover periods (e.g., wk 1 to 3,4 to 6,1 to 6,8 to 32 , and 1 to 32 ) using mixed models fitted with REML, including treatment and contrasts to test MF, duration, and their interaction as fixed effects, and cow as a random effect. Data for SCC, GH, insulin, IGF-1, AST, and GDH were logarithmically transformed before statistical analyses. Body condition score and BW 
at 1 wk prepartum (mean $\pm \mathrm{SD} ; 5.1 \pm 0.5$ BCS units; $561 \pm 63 \mathrm{~kg} \mathrm{BW}$ ) were used as covariates for analysis of BCS and BW data, respectively.

$t$-Tests were used for individual treatment comparisons if significant MF $\times$ duration interactions were detected. Estimated PPAI were logarithmically transformed and analyzed using the CENSOR procedure in GenStat software, and submission, conception, and pregnancy rates were analyzed using generalized linear models with binomial error distribution.

Least squared means and the standard error of the difference between means are presented. The standard error of the difference between means $\times \sqrt{0.75}$ should be used to compare the mean of $1 \times$ or $3 \times$ treatments with each other and the $2 \times$ control. Differences in data are considered significant at $P<0.05$ and declared a trend at $P \leq 0.10$.

\section{RESULTS AND DISCUSSION}

Temporarily milking cows $1 \times$ for 3 or 6 wk immediately postpartum reduced yields of milk and milk components during the period of reduced MF (i.e., immediate effect) and after cows were changed to $2 \times$ milking (i.e., carryover effect; Table 2; Figure $1 \mathrm{~A}$ and B). By comparison, milking cows $3 \times$ had immediate positive effects on milk yield, but carryover effects were not as prominent. Consistent with the altered energy output for milk production, plasma metabolite, hormone, and liver enzyme concentrations, along with BCS profiles, indicated an increasing state of negative energy balance with increasing postpartum MF. Therefore, as little as 3 wk of altered postpartum MF affected the whole-lactation production and energy status of pasture-grazed dairy cows.

\section{Postpartum MF Affected Whole-Lactation Production}

Cows milked $1 \times$ produced less milk $(-15 \%)$, ECM $(-17 \%)$, fat $(-19 \%)$, protein $(-14 \%)$, and lactose $(-17 \%)$ per day during wk 1 to 3 postpartum than cows milked $2 \times$ (Table 2; Figure 1A and B). Furthermore, the size of these milk production losses increased by approximately $5 \%$ during wk 4 to 6 for cows that remained on $1 \times$ milking for 6 wk postpartum (Table 2; Figure $1 \mathrm{~A}$ and $\mathrm{B}$ ). These results imply that the immediate daily reduction in milk and milk component yields increased with duration of $1 \times$ milking, as previously reported (Rémond et al., 1999; Rémond and Pomiès, 2005). The size of these immediate milk yield losses are slightly less than the 24 to $40 \%$ decreases reported for housed cows fed a mixed ration and milked $1 \times$ for up to 6 wk postpartum (Rémond et al., 1999; McNamara et al., 2008; Loiselle et al., 2009; Schlamberger et al.,
2010); nevertheless, they are consistent with the 10 to $27 \%$ decreases in milk yield reported for pasture-grazed cows during $1 \times$ milking in early to mid lactation (Carruthers et al., 1993; Kay et al., 2013; Stelwagen et al., 2013).

Conversely, increasing the MF of grazing cows to $3 \times$ at the start of lactation induced an immediate increase in milk yield $(+7 \%$; Table 2 ; Figure $1 \mathrm{~A})$ compared with cows milked $2 \times$. The increase in milk yield from $2 \times$ to $3 \times$ milking was similar to the $8 \%$ increase previously reported for 8 wk of $3 \times$ milking postpartum in housed cows fed TMR (Andersen et al., 2003). It also falls within the 5 to $25 \%$ range of responses to $3 \times$ milking reported previously (Erdman and Varner, 1995; Stockdale, 2006; Wall and McFadden, 2008). Unlike the duration effect in cows milked $1 \times$, no effect of the duration of $3 \times$ milking was detected on the amount of milk produced during the first 6 wk of lactation (Table 2; Figure 1A), indicating that a longer period of increased MF did not lead to further production increases.

Cows milked $3 \times$ postpartum produced more dilute milk than cows milked $2 \times$ from calving, with lower milk $\mathrm{NE}_{\mathrm{L}}$, and lower milk fat, protein, and lactose contents but a greater protein:fat ratio during the first $6 \mathrm{wk}$ of lactation (Table 2; Figure 1C, D, and E). Furthermore, differences in composition remained long after cows had switched to $2 \times$ milking (i.e., during wk 8 to 32; Table 2; Figure 1C and D). Wall and McFadden (2008) reported that the published effect of $3 \times$ milking on milk composition is inconsistent, with no change relative to $2 \times$ in some studies, but decreases in milk fat content in others. In general, differences reported are small relative to the increase in milk production, and yields of milk components increase with $3 \times$ milking. In the present study, the moderate increase in milk volume was not sufficient to offset the large decreases in milk component concentrations. Consequently, milk fat, protein, lactose, and ECM yields were similar between cows milked $3 \times$ postpartum and $2 \times$ at all stages of the experiment (Table 2; Figure 1B).

The effects of $1 \times$ milking on milk composition were less dramatic. During the first 6 wh of lactation, cows milked $1 \times$ for 3 or 6 wk postpartum had a lower lactose content, a greater protein:fat ratio, and tended to have a greater protein $(P=0.10)$ and a lower milk fat content $(P=0.06)$ than those milked $2 \times$ from calving (Table 2; Figure 1C, D, and E). Reduced milk lactose content is typical of cows milked $1 \times$ (Davis et al., 1999; Rémond and Pomiès, 2005; Stelwagen et al., 2013); in contrast, the tendency for a lower milk fat content was surprising. In previous studies, either no change (Rémond et al., 2002; McNamara et al., 2008) or a greater milk fat content relative to cows milked $2 \times$ was reported (Rémond et al., 1999; Schlamberger 
Table 2. Mean milk production and composition of pasture-based cows milked twice daily $(2 \times$; control), once daily $(1 \times)$ for 3 or 6 wk immediately postpartum and $2 \times$ thereafter $\left(1 \times \_3\right.$ wk and $1 \times \_6$ wk, respectively), or 3 times daily $(3 \times)$ for 3 or 6 wk immediately postpartum and $2 \times$ thereafter $\left(3 \times \_3\right.$ wk and $3 \times \_6$ wk, respectively)

\begin{tabular}{|c|c|c|c|c|c|c|c|c|c|c|c|}
\hline \multirow[b]{2}{*}{ Item } & \multirow[b]{2}{*}{$\begin{array}{c}\text { Week } \\
\text { postpartum }\end{array}$} & \multicolumn{5}{|c|}{ Treatment } & \multirow[b]{2}{*}{$\mathrm{SED}^{1}$} & \multicolumn{4}{|c|}{$P$-value } \\
\hline & & $1 \times \_3 w k$ & $1 \times \_6 w k$ & $2 \times$ & $3 \times \_3 w k$ & $3 \times \_6 w k$ & & $1 \times$ vs. $2 \times$ & $3 \times$ vs. $2 \times$ & $3 \times$ vs. $1 \times$ & $\underset{\text { duration }^{2}}{\mathrm{MF} \times}$ \\
\hline \multirow[t]{4}{*}{ Milk, kg/d } & 1 to 3 & 19.2 & 18.4 & 22.2 & 24.1 & 23.5 & 0.87 & $<0.001$ & $<0.05$ & $<0.001$ & 0.78 \\
\hline & 4 to 6 & 24.1 & 20.2 & 25.3 & 26.1 & 27.6 & 1.01 & 0.001 & 0.07 & $<0.001$ & $<0.001$ \\
\hline & 1 to 6 & 21.7 & 19.3 & 23.7 & 25.1 & 25.6 & 0.90 & $<0.001$ & $<0.05$ & $<0.001$ & $<0.05$ \\
\hline & 8 to 32 & 20.3 & 20.0 & 21.3 & 22.7 & 21.9 & 0.77 & 0.08 & 0.14 & $<0.001$ & 0.68 \\
\hline \multirow[t]{4}{*}{$\mathrm{ECM},{ }^{3} \mathrm{~kg} / \mathrm{d}$} & 1 to 3 & 21.8 & 20.7 & 25.6 & 26.4 & 26.3 & 1.08 & $<0.001$ & 0.43 & $<0.001$ & 0.52 \\
\hline & 4 to 6 & 25.9 & 21.4 & 27.5 & 27.3 & 28.1 & 1.07 & $<0.001$ & 0.84 & $<0.001$ & $<0.001$ \\
\hline & 1 to 6 & 23.8 & 21.1 & 26.6 & 26.8 & 27.2 & 1.00 & $<0.001$ & 0.60 & $<0.001$ & 0.03 \\
\hline & 8 to 32 & 22.1 & 21.5 & 23.6 & 23.9 & 23.0 & 0.72 & $<0.01$ & 0.75 & 0.001 & 0.74 \\
\hline \multirow[t]{4}{*}{ Fat, $\mathrm{kg} / \mathrm{d}$} & 1 to 3 & 0.92 & 0.87 & 1.10 & 1.10 & 1.11 & 0.052 & $<0.001$ & 0.94 & $<0.001$ & 0.44 \\
\hline & 4 to 6 & 1.07 & 0.88 & 1.17 & 1.12 & 1.15 & 0.051 & $<0.001$ & 0.39 & $<0.001$ & $<0.01$ \\
\hline & 1 to 6 & 1.00 & 0.88 & 1.14 & 1.11 & 1.13 & 0.047 & $<0.001$ & 0.65 & $<0.001$ & $<0.05$ \\
\hline & 8 to 32 & 0.92 & 0.89 & 1.00 & 0.98 & 0.94 & 0.033 & 0.001 & 0.14 & $<0.05$ & 0.83 \\
\hline \multirow[t]{4}{*}{ Protein, kg/d } & 1 to 3 & 0.76 & 0.72 & 0.86 & 0.90 & 0.89 & 0.036 & $<0.001$ & 0.21 & $<0.001$ & 0.58 \\
\hline & 4 to 6 & 0.88 & 0.73 & 0.90 & 0.92 & 0.93 & 0.034 & 0.001 & 0.30 & $<0.001$ & $<0.001$ \\
\hline & 1 to 6 & 0.82 & 0.72 & 0.88 & 0.91 & 0.91 & 0.032 & $<0.001$ & 0.22 & $<0.001$ & $<0.05$ \\
\hline & 8 to 32 & 0.75 & 0.72 & 0.79 & 0.82 & 0.78 & 0.024 & $<0.01$ & 0.71 & $<0.001$ & 0.66 \\
\hline \multirow{4}{*}{ Lactose, $\mathrm{kg} / \mathrm{d}$} & 1 to 3 & 0.91 & 0.86 & 1.07 & 1.13 & 1.10 & 0.041 & $<0.001$ & 0.21 & $<0.001$ & 0.81 \\
\hline & 4 to 6 & 1.17 & 0.97 & 1.23 & 1.26 & 1.31 & 0.048 & $<0.001$ & 0.18 & $<0.001$ & $<0.001$ \\
\hline & 1 to 6 & 1.04 & 0.92 & 1.15 & 1.20 & 1.21 & 0.043 & $<0.001$ & 0.17 & $<0.001$ & $<0.05$ \\
\hline & 8 to 32 & 0.98 & 0.97 & 1.04 & 1.10 & 1.07 & 0.037 & 0.05 & 0.17 & $<0.001$ & 0.73 \\
\hline \multirow[t]{4}{*}{ Fat, $\%$} & 1 to 3 & 4.85 & 4.81 & 5.02 & 4.67 & 4.78 & 0.139 & 0.12 & $<0.05$ & 0.28 & 0.47 \\
\hline & 4 to 6 & 4.48 & 4.44 & 4.66 & 4.32 & 4.19 & 0.140 & 0.10 & 0.001 & $<0.05$ & 0.64 \\
\hline & 1 to 6 & 4.66 & 4.61 & 4.83 & 4.48 & 4.47 & 0.118 & 0.06 & 0.001 & 0.05 & 0.83 \\
\hline & 8 to 32 & 4.63 & 4.55 & 4.77 & 4.40 & 4.35 & 0.131 & 0.12 & 0.001 & $<0.05$ & 0.93 \\
\hline \multirow[t]{4}{*}{ Protein, $\%$} & 1 to 3 & 4.04 & 4.03 & 3.95 & 3.85 & 3.90 & 0.062 & 0.12 & 0.16 & $<0.001$ & 0.47 \\
\hline & 4 to 6 & 3.64 & 3.60 & 3.56 & 3.53 & 3.38 & 0.054 & 0.14 & $<0.05$ & $<0.001$ & 0.13 \\
\hline & 1 to 6 & 3.84 & 3.81 & 3.75 & 3.68 & 3.63 & 0.051 & 0.10 & $<0.05$ & $<0.001$ & 0.81 \\
\hline & 8 to 32 & 3.69 & 3.64 & 3.72 & 3.62 & 3.57 & 0.059 & 0.30 & $<0.05$ & 0.09 & 0.97 \\
\hline \multirow{4}{*}{ Lactose, $\%$} & 1 to 3 & 4.68 & 4.67 & 4.80 & 4.66 & 4.66 & 0.029 & $<0.001$ & $<0.001$ & 0.53 & 0.99 \\
\hline & 4 to 6 & 4.86 & 4.78 & 4.88 & 4.83 & 4.76 & 0.025 & $<0.01$ & $<0.001$ & 0.10 & 0.90 \\
\hline & 1 to 6 & 4.77 & 4.73 & 4.84 & 4.75 & 4.71 & 0.024 & $<0.001$ & $<0.001$ & 0.19 & 0.88 \\
\hline & 8 to 32 & 4.84 & 4.86 & 4.87 & 4.84 & 4.85 & 0.028 & 0.30 & 0.21 & 0.79 & 0.94 \\
\hline \multirow[t]{4}{*}{$\mathrm{NE}_{\mathrm{L}},{ }^{4} \mathrm{MJ} / \mathrm{kg}$ of milk } & 1 to 3 & 3.53 & 3.53 & 3.60 & 3.42 & 3.49 & 0.061 & 0.18 & $<0.01$ & 0.09 & 0.42 \\
\hline & 4 to 6 & 3.36 & 3.32 & 3.42 & 3.27 & 3.18 & 0.060 & 0.14 & $<0.001$ & $<0.01$ & 0.54 \\
\hline & 1 to 6 & 3.45 & 3.43 & 3.51 & 3.34 & 3.33 & 0.053 & 0.11 & $<0.001$ & $<0.01$ & 0.80 \\
\hline & 8 to 32 & 3.44 & 3.40 & 3.50 & 3.33 & 3.30 & 0.061 & 0.11 & 0.001 & $<0.05$ & 0.95 \\
\hline \multirow{4}{*}{ Protein:fat ratio } & 1 to 3 & 0.84 & 0.84 & 0.79 & 0.83 & 0.81 & 0.024 & 0.02 & 0.18 & 0.20 & 0.75 \\
\hline & 4 to 6 & 0.83 & 0.84 & 0.78 & 0.83 & 0.83 & 0.024 & $<0.01$ & $<0.01$ & 0.96 & 0.67 \\
\hline & 1 to 6 & 0.84 & 0.84 & 0.78 & 0.83 & 0.82 & 0.020 & $<0.01$ & $<0.05$ & 0.44 & 0.63 \\
\hline & 8 to 32 & 0.82 & 0.81 & 0.79 & 0.84 & 0.84 & 0.018 & 0.21 & $<0.01$ & 0.06 & 0.89 \\
\hline \multirow{4}{*}{$\log _{10} \mathrm{SCC}, \times 1,000$ cells $/ \mathrm{mL}$} & 1 to 3 & 1.90 & 1.90 & 1.88 & 1.83 & 1.91 & 0.088 & 0.79 & 0.91 & 0.64 & 0.56 \\
\hline & 4 to 6 & 1.74 & 1.90 & 1.69 & 1.83 & 1.78 & 0.100 & 0.15 & 0.20 & 0.85 & 0.13 \\
\hline & 1 to 6 & 1.82 & 1.90 & 1.79 & 1.82 & 1.84 & 0.086 & 0.34 & 0.57 & 0.63 & 0.58 \\
\hline & 8 to 32 & 1.87 & 1.91 & 1.85 & 1.79 & 1.87 & 0.102 & 0.60 & 0.86 & 0.39 & 0.76 \\
\hline
\end{tabular}

${ }^{1}$ Standard error of the difference between means. The SED $\times \sqrt{0.75}$ should be used to compare the mean of $1 \times$ or $3 \times$ treatments with each other and the $2 \times$ control.

$\Rightarrow \quad{ }^{2}$ Milking frequency $(1 \times, 2 \times$, or $3 \times)$ by duration $(3$ or 6 wk) interaction.

$\quad{ }^{3}$ Energy-corrected milk was calculated as kilograms of ECM per cow per day $=$ kilograms of milk per day $\times[(383 \times$ fat $\%)+(242 \times$ protein $\left.\%)+783.2)\right] / 3,140($ Tyrrell and Reid, 1965$)$

${ }^{4}$ Milk NE $E_{\mathrm{L}}$ was calculated as megajoules per kilogram of milk $=4.186 \mathrm{MJ} / \mathrm{Mcal} \times[(0.0929 \times$ fat \% $)+(0.0547 \times \mathrm{CP} \%)+(0.0395 \times$ lactose $\%)](\mathrm{NRC}, 2001)$. 

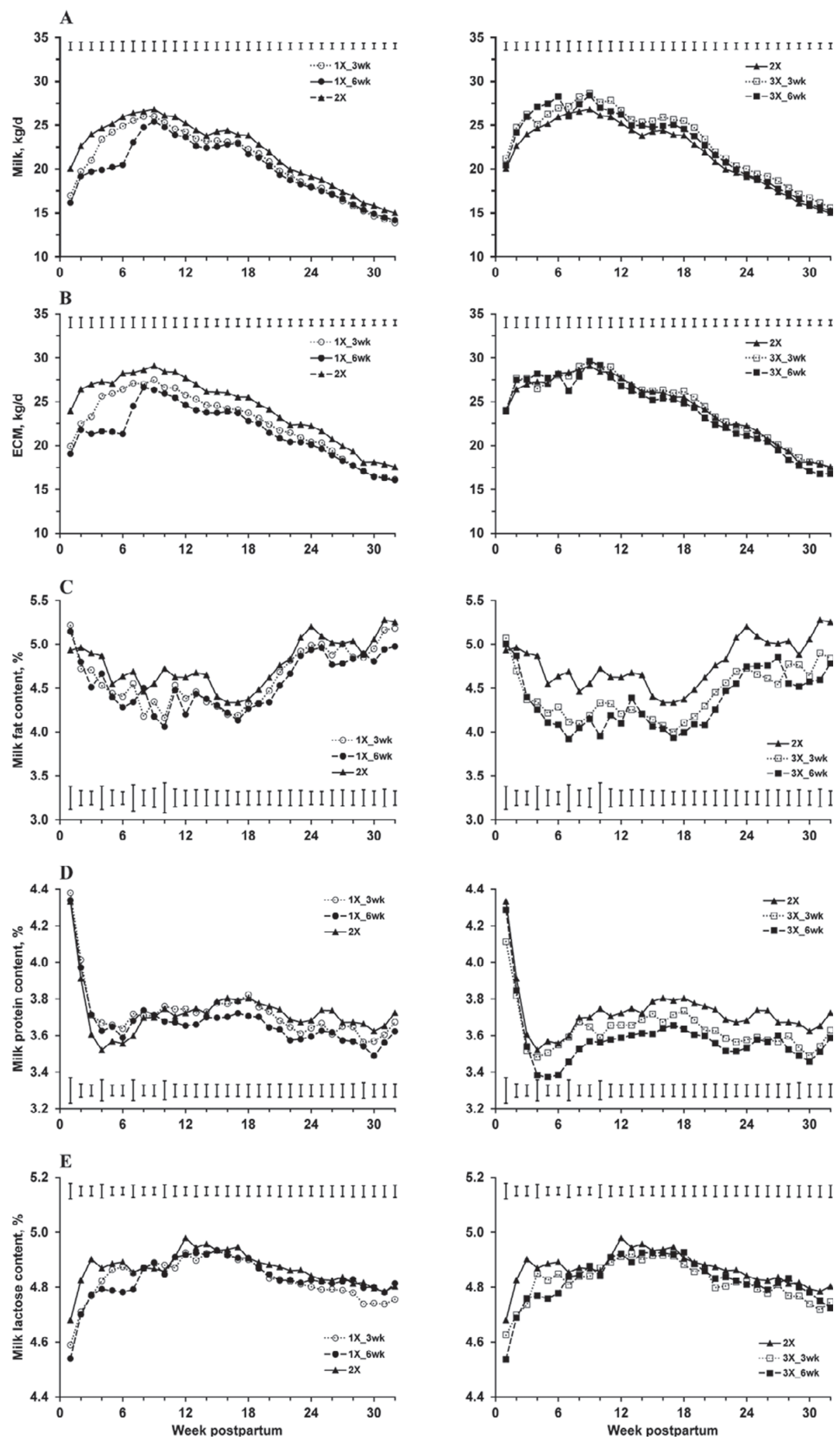

Figure 1. Daily milk production and milk composition of cows milked twice daily $(2 \times$; control), once daily $(1 \times)$ for 3 or 6 wk postpartum and $2 \times$ thereafter $\left(1 \times \_3\right.$ wk and $1 \times \_6$ wk, respectively), or 3 times daily $(3 \times)$ for 3 or 6 wk postpartum and $2 \times$ thereafter $\left(3 \times \_3 w k\right.$ and $3 \times \_6$ wk, respectively); (A) milk and (B) ECM yields, and (C) milk fat, (D) protein, and (E) lactose contents. Mean values with the SE of the difference between means are presented. For clarity, $1 \times$ and $3 \times$ treatments are presented on separate figures with the $2 \times$ control. 
et al., 2010). A decreased milk fat content, however, is consistent with reduced activity (Farr et al., 1995) and transcription (Grala et al., 2011) of mammary enzymes involved in milk fat synthesis, and the lower circulating NEFA concentrations in cows milked $1 \times$ (Figure $2 \mathrm{~B}$ ). Nonetheless, across previous experiments, any increases in milk fat and protein content during $1 \times$ milking did not fully compensate for the reduced milk volume yield relative to $2 \times$, resulting in reduced milk fat and protein yields as in the current study.

Milking cows $1 \times$ for a short duration immediately postpartum also resulted in long-term negative effects on milk production. During wk 8 to 32 postpartum, when all cows were milked $2 \times$, cows previously milked $1 \times$ (for 3 or $6 \mathrm{wk})$ had lower average daily milk $(-6 \%$;
$P=0.08)$, ECM $(-8 \%)$, fat $(-10 \%)$, protein $(-7 \%)$, and lactose $(-6 \% ; P=0.06)$ yields than cows continuously milked $2 \times$ (Table 2 ). This effect was still present at wk 32 (i.e., 224 DIM; Figure 1A and B), and contributed to an approximately $10 \%$ reduction in cumulative milk and milk component yields by the end of lactation (Table 3). Nevertheless, DIM was not affected as all postpartum milking frequency treatments resulted in a similar lactation length $(280 \pm 18.2 \mathrm{DIM})$. A residual effect of a lower postpartum MF is supported by several recent studies. In cows housed and fed TMR until turnout to pasture at wk 6 postpartum, $1 \times$ compared with $2 \times$ milking for the first 4 wk postpartum resulted in a continued loss of milk production that was sustained for $11 \mathrm{wk}$, but not thereafter (McNamara et al., 2008).
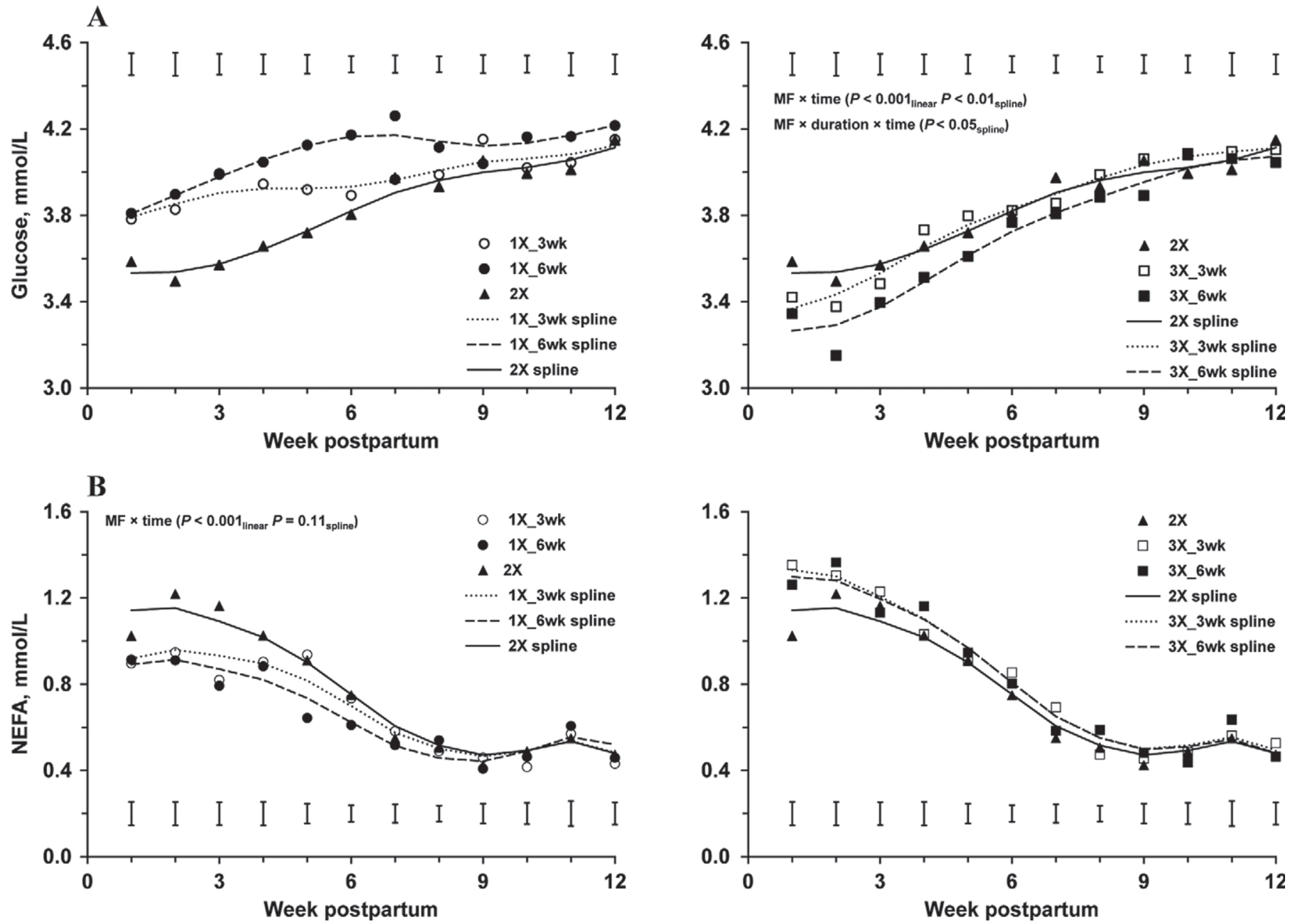

Figure 2. Plasma concentrations (weekly means and fitted splines) of (A) glucose and (B) NEFA during early lactation in cows milked twice daily $\left(2 \times\right.$; control), once daily $(1 \times)$ for 3 or 6 wk postpartum and $2 \times$ thereafter $\left(1 \times \_3\right.$ wk and $1 \times \_6$ wk, respectively), or 3 times daily $(3 \times)$ for 3 or 6 wk postpartum and $2 \times$ thereafter $\left(3 \times \_3\right.$ wk and $3 \times \_6$ wk, respectively). Mean values with the SE of the difference between means are presented. For clarity, $1 \times$ and $3 \times$ treatments are presented on separate figures with the $2 \times$ control. $P$-values for the fitted slopes are presented only if significant $(P<0.05)$ or a trend $(P \leq 0.12)$. MF $\times$ time $=$ interaction between milking frequency $(1 \times, 2 \times$, or $3 \times)$ and time; MF $\times$ duration $\times$ time $=$ interaction between milking frequency $(1 \times, 2 \times$, or $3 \times)$, duration $(3$ or $6 \mathrm{wk})$, and time. 
Table 3. Cumulative milk production of pasture-based cows milked twice daily $(2 \times$; control), once daily $(1 \times)$ for 3 or 6 wk immediately postpartum and $2 \times$ thereafter, or 3 times daily $(3 \times)$ for 3 or 6 wk immediately postpartum and $2 \times$ thereafter $^{1}$

\begin{tabular}{|c|c|c|c|c|c|c|c|c|}
\hline Item & Period & \multicolumn{3}{|c|}{ Treatment } & $\mathrm{SED}^{2}$ & \multicolumn{3}{|c|}{$P$-value } \\
\hline Milk, kg & Total $^{3}$ & 5,114 & 5,618 & 5,762 & 185.8 & $<0.01$ & 0.46 & $<0.001$ \\
\hline \multirow[t]{2}{*}{$\mathrm{ECM},{ }^{4} \mathrm{~kg}$} & wk $1-32$ & 4,934 & 5,446 & 5,427 & 144.3 & 0.001 & 0.86 & $<0.001$ \\
\hline & Total & 5,584 & 6,283 & 6,069 & 190.3 & $<0.001$ & 0.26 & $<0.01$ \\
\hline Fat, $\mathrm{kg}$ & wk 1-32 & 206 & 231 & 223 & 6.6 & $<0.001$ & 0.19 & $<0.01$ \\
\hline Protein, $\mathrm{kg}$ & Total & 189 & 210 & 207 & 6.3 & 0.001 & 0.56 & 0.001 \\
\hline \multirow{2}{*}{ Lactose, $\mathrm{kg}$} & wk 1-32 & 221 & 239 & 249 & 7.1 & $<0.01$ & 0.18 & $<0.001$ \\
\hline & Total & 246 & 272 & 275 & 9.0 & $<0.01$ & 0.73 & $<0.001$ \\
\hline
\end{tabular}

\footnotetext{
${ }^{1}$ No interactions $(P>0.10)$ were detected between milking frequency $(1 \times, 2 \times$, or $3 \times)$ and duration $(3$ or 6 wk) for any of the variables measured; hence, only the main effects of milking frequency are presented.

${ }^{2}$ Standard error of the difference between means.

${ }^{3}$ Total $=$ full-lactation yield from calving to dry-off.

${ }^{4}$ Energy-corrected milk was calculated as kilograms of ECM per cow per day $=$ kilograms of milk per day $\times[(383 \times$ fat $\%)+(242 \times$ protein $\%)+783.2)] / 3,140$ (Tyrrell and Reid, 1965).
}

In addition, Schlamberger et al. (2010) reported that ECM yields from high-producing, housed cows were 10 to $17 \%$ lower for the remainder of lactation due to $1 \times$ milking for $4 \mathrm{wk}$ postpartum. The present study indicates that sustained losses in milk production also occur in lower-yielding dairy cows grazing pasture from calving, which will lead to losses in annual milk revenue per cow.

The long-term decreases in milk and milk component yields were similar, regardless of the duration of $1 \times$ milking postpartum (Table 2 ). This outcome differs from that of Rémond et al. (1999), who reported greater carryover losses in milk yield for 6 wk relative to 3 wk of $1 \times$ milking postpartum in housed cows, and significant carryover losses in milk fat and protein yields for $6 \mathrm{wk}$ but not $3 \mathrm{wk}$ of $1 \times$ milking; however, the carryover effects in that study may have been influenced by low cow numbers per treatment combined with a high incidence of clinical mastitis. Indeed, residual decreases in both milk and milk component yields following $3 \mathrm{wk}$ of $1 \times$ milking in early lactation were recently reported by Kay et al. (2013), even in low-producing cows $(<4,000 \mathrm{~kg}$ of milk/yr). It appears that some physiological factors altered to reduce milk production under $1 \times$ milking (Stelwagen, 2001) are irreversibly changed with only a short period of reduced MF at this stage of lactation. Therefore, limiting the duration of $1 \times$ milking to $3 \mathrm{wk}$ during early lactation does not prevent sustained reductions in milk and milk component yields in grazing cows.

In contrast to the residual effects of $1 \times$ milking, very little long-term differences were detected between cows previously milked $3 \times$ and those milked $2 \times$ from calving. However, a numerically greater daily milk yield was detected during wk 8 to $32(+5 \% ; P=0.14$; Table 2$)$ in cows milked $3 \times$ postpartum relative to cows continuously milked $2 \times$, which slightly improved cumulative milk yields between wk 1 to $32(+5 \% ; P=0.11$; Table 3 ). Considerable evidence exists that this positive carryover effect of increased postpartum MF is real (Hale et al., 2003; Dahl et al., 2004; Wall et al., 2006). The lack of a significant carryover increase may simply reflect a lack of statistical power to detect the difference, despite the relatively large numbers of cows used (n $=\sim 30$ cows per treatment; $\mathrm{n}=60$ cows milked $3 \times$ ). Nevertheless, even if real, the effect on milk volume was small and total ECM, protein, and lactose productions to dry-off were not increased. Furthermore, total fat production was actually $7 \%$ less in cows temporarily milked $3 \times$ postpartum (Table 3 ) due to their persistently lower milk fat content.

The reason for the relatively small immediate response to $3 \times$ milking (and the subsequent lack of a significant carryover effect) is not clear. It may reflect an insufficient energy intake in cows milked $3 \times$ postpartum under a pasture-based diet with moderate concentrate supplementation (4 kg of DM/cow per day). The insufficient energy intakes that typically occur postpartum may also be magnified due to reduced grazing time because cows are removed for a third milking. Similarly, McNamara et al. (2008) reported that milking cows $3 \times$ during the first 4 wk of lactation did not affect immediate or long-term milk production, possibly due to reduced access to TMR and, consequently, a slightly lower DMI relative to milking $2 \times$. Andersen et al. (2003) suggested that higher-energy-density diets may be required during $3 \times$ milking postpartum because the increase in milk yield is not accompanied by an increase in DMI 
and, consequently, cows mobilize more body reserves. Energy intakes were not measured in the present study due to the inherent difficulties of measuring individual DMI under grazing conditions. However, cows milked $3 \times$ had a greater $(P<0.05)$ plasma NEFA concentration (Figure 2B) and BCS loss (Figure 3A) during the first week postpartum than cows milked $2 \times$, indicating that they initially mobilized extra body fat to support their greater requirements for milk production. Greater milk and milk components yields over both the short and long term in response to temporary $3 \times$ milking in grazing cows may occur with a more energy-dense diet, requiring a greater rate of concentrate supplementation than that offered in the present study.

A further reason for the lack of a long-term effect from an increased postpartum MF may have been that $3 \times$ milking was not sufficient to generate the expected response. Several studies (Hale et al., 2003; Dahl et al., 2004; Wall et al., 2006) have confirmed immediate and lactation-long increases in milk yield from milking high-producing cows 4 times daily for 3 wk postpartum in housed high-input systems. Given that this strategy would be expected to magnify any reductions in DMI that would occur due to reduced access time to pasture, it is unlikely that a further increase in MF beyond $3 \times$ would result in these responses in grazing cows, unless a very high proportion of the diet consisted of energydense supplements. Irrespective of why no carryover effect existed in the current study, the results imply that $3 \times$ milking for a short period at the beginning of lactation does not increase the yield of milk components and may, in fact, reduce milk revenue per cow in pricing systems based on milk components with penalties for milk volume.
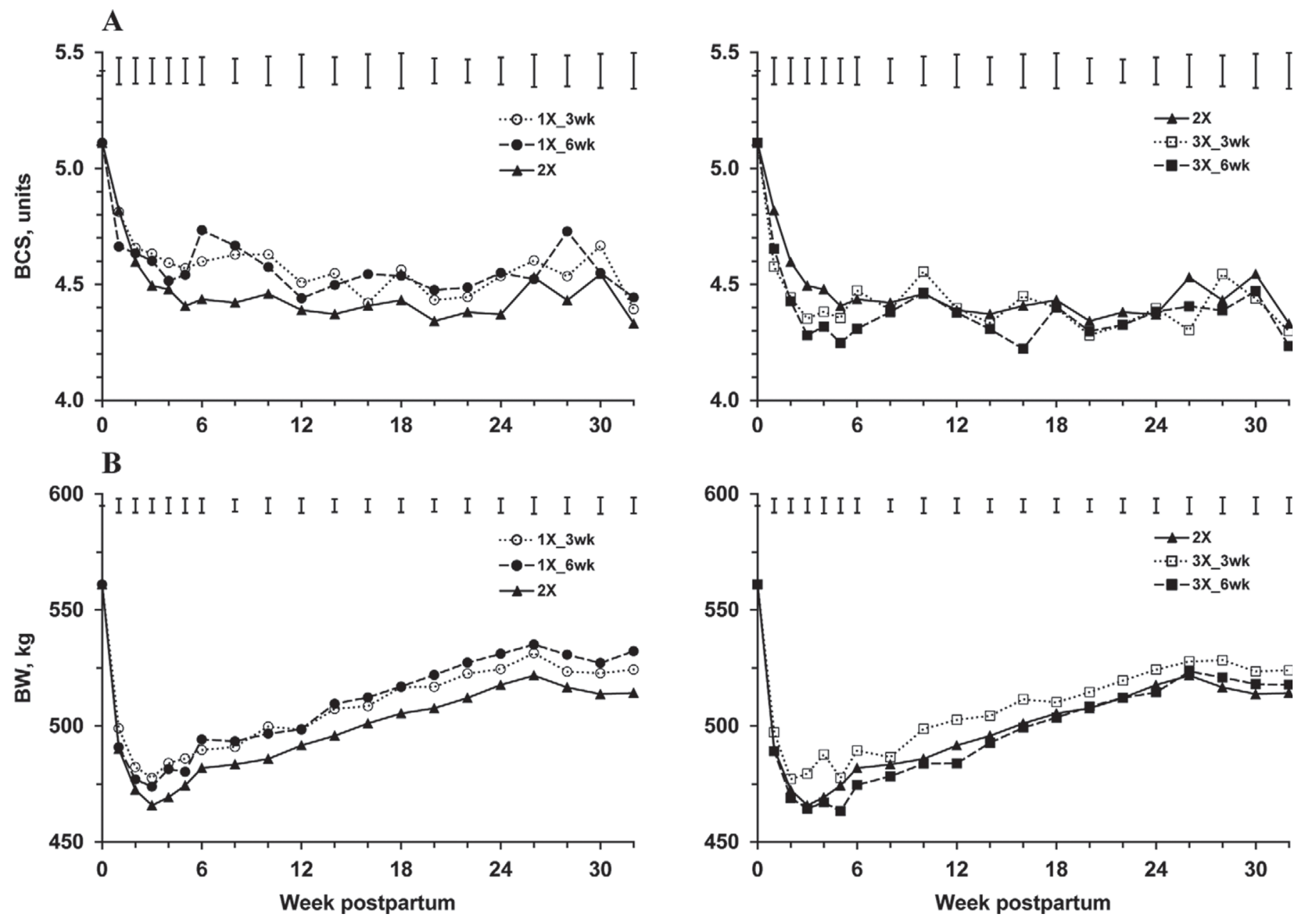

Figure 3. (A) Body condition score (1 to 10 scale; Roche et al., 2004) and (B) BW of cows milked twice daily (2×; control), once daily $(1 \times)$ for 3 or 6 wk postpartum and $2 \times$ thereafter $\left(1 \times \_3\right.$ wk and $1 \times \_6$ wk, respectively), or 3 times daily $(3 \times)$ for 3 or 6 wk postpartum and $2 \times$ thereafter $\left(3 \times \_3 w k\right.$ and $3 \times \_6 w k$, respectively). Mean values with the SE of the difference between means are presented. For clarity, $1 \times$ and $3 \times$ treatments are presented on separate figures with the $2 \times$ control. 
Identifying the physiological mechanisms regulating the immediate and long-term responses to MF may enable the development of strategies to maximize milk production efficiencies for $1 \times$ and $3 \times$ milking. The effects of MF on milk production are controlled by local, intramammary signals (Davis et al., 1999; Stelwagen, 2001; Wall and McFadden, 2008, 2012). These mechanisms are yet to be fully characterized, but are attributed to chemical (Wilde et al., 1995; Shamay et al., 1997; Matsuda et al., 2004) or physical (Davis et al., 1999; Stelwagen, 2001) feedback signaling in response to milk accumulation/removal in the mammary gland. Ultimately, these local signals regulate milk production through the number and activity of mammary secretory cells (Stelwagen, 2001). Indeed, $1 \times$ milking reduces the activity of key mammary enzymes involved in milk fat and lactose synthesis (Farr et al., 1995), and downregulates the expression of genes involved in milk fat, protein, and lactose synthesis (Boutinaud et al., 2008; Littlejohn et al., 2010; Grala et al., 2011). Furthermore, Grala et al. (2011) reported that transcription of milk synthesis genes remained lower even after cows milked $1 \times$ postpartum were switched to $2 \times$. Evidence was also presented that $1 \times$ milking decreased mammary cell number, as the transcription of genes promoting cell death via apoptosis was greater during and after the reduced MF (Grala et al., 2011). Both reduced mammary secretory cell number and activity may, therefore, contribute to the sustained decreases in milk production following temporary $1 \times$ milking.

The positive effects of increased MF on milk production may reflect greater proliferation or differentiation of mammary cells, extracellular remodeling, or creation of new blood vessels (Hillerton et al., 1990; Hale et al., 2003; Connor et al., 2008). However, the role of these processes is not consistent across the literature, with several authors reporting that increases in milk production with frequent milking were not associated with greater mammary epithelial cell proliferation (Nørgaard et al., 2005; Wall et al., 2006; Soberon et al., 2010; Wall and McFadden, 2010). In addition, Grala et al. (2011) reported that increases in milk yield from $3 \times$ milking were not associated with changes in milk synthesis gene expression, indicating that mammary cell activity was not increased. The recent identification of a mammary transcriptional "signature" during the early stages (d 5) of frequent milking postpartum (Wall et al., 2012; Wall and McFadden, 2012) indicates that the increase in milk yield may be mediated by genes that are also acutely regulated by milk removal from the mammary gland, including the downregulation of acute-phase/inflammatory response genes. These data, combined with further sequential analyses of mammary gene expression during and after an altered postpartum
MF, may provide greater insights into the mechanisms controlling the production responses (immediate and carryover) to the frequency of milk removal.

\section{Postpartum MF Affected Cow Metabolic Status and BCS}

Plasma metabolic profiles were consistent with a more severe state of negative energy balance with increasing postpartum MF. The temporal patterns of plasma glucose and NEFA concentrations during the first 12 wk of lactation were altered by postpartum MF (Figure 2A and B), with the effect on glucose profiles dependent upon the duration of the MF strategy (MF $\times$ duration $\times$ time interaction spline; $P<0.05$; Figure $2 \mathrm{~A})$. During the first 3 wk of lactation, cows milked $1 \times$ had consistently greater $(P<0.05)$ plasma glucose concentrations compared with those milked $2 \times$ (Table 4 ; Figure 2A), whereas NEFA concentrations were lower in cows milked $1 \times$ relative to $2 \times$ (Table 4 ), primarily due to differences at wk $2(P<0.01)$ and wk $3(P<$ 0.001; Figure 2B). This increase in plasma glucose and decrease in plasma NEFA during $1 \times$ milking concurs with previous studies in both grazed cows (Auldist and Prosser, 1998; Kay et al., 2013) and high-producing, housed cows (Rémond et al., 1999; McNamara et al., 2008; Loiselle et al., 2009; Schlamberger et al., 2010), with the latter also reported to have a less negative (or more positive) calculated energy balance (Rémond et al., 1999; McNamara et al., 2008). In contrast, cows milked $3 \times$ had lower glucose, but greater NEFA, concentrations during wk 1 to 3 compared with cows milked $2 \times$ (Table 4 ), mainly because of differences $(P$ $<0.05$ ) during the first week postpartum (Figure 2A and B). Similar metabolic responses to increased postpartum MF were reported in housed cows (Bar-Peled et al., 1995; Eslamizad et al., 2010; Soberon et al., 2010). Collectively, these results indicate that milking cows $1 \times$ during the first $3 \mathrm{wk}$ of lactation improved their energy status, whereas milking cows $3 \times$ induced a greater degree of negative energy balance.

Consistent with this positive effect of reduced MF on cow energy status, MF $\times$ duration interactions $(P$ $<0.05)$ existed for glucose and NEFA concentrations during wk 4 to 6 (Table 4; Figure 2A and B), with cows remaining on $1 \times$ milking continuing to have greater glucose $(P<0.05)$ and lower NEFA $(P<0.05)$ concentrations than cows milked $2 \times$ from calving. In addition, cows switched from $1 \times$ to $2 \times$ milking at 3 wk postpartum still had greater $(P<0.05)$ glucose concentrations at wk 4 and 5 (Figure $2 \mathrm{~A}$ ), indicating a positive effect of $1 \times$ milking on cow energy status beyond the period of reduced MF. A transient residual effect on plasma glucose concentrations was also evident at wk 7 
Table 4. Mean plasma concentrations of metabolites, hormones, and liver enzymes during the first 12 wk postpartum of pasture-based cows milked twice daily ( $2 \times$; control), once daily $(1 \times)$ for 3 or 6 wk immediately postpartum and $2 \times$ thereafter $\left(1 \times \_3 w k\right.$ and $1 \times \_6$ wk, respectively), or 3 times daily $(3 \times)$ for 3 or 6 wk immediately postpartum and $2 \times$ thereafter $\left(3 \times \_3 \text { wk and } 3 \times \_6 \text { wk, respectively }\right)^{1}$

\begin{tabular}{|c|c|c|c|c|c|c|c|c|c|c|c|}
\hline \multirow[b]{2}{*}{ Item $^{2}$} & \multirow[b]{2}{*}{$\begin{array}{c}\text { Week } \\
\text { postpartum }\end{array}$} & \multicolumn{5}{|c|}{ Treatment } & \multirow[b]{2}{*}{$\mathrm{SED}^{3}$} & \multicolumn{4}{|c|}{$P$-value } \\
\hline & & $1 \times \_3 w k$ & $1 \times \_6 w k$ & $2 \times$ & $3 \times \_3 w k$ & $3 \times \_6 w k$ & & $1 \times$ vs. $2 \times$ & $3 \times$ vs. $2 \times$ & $3 \times$ vs. $1 \times$ & $\begin{array}{c}\text { MF } \times \\
\text { duration }\end{array}$ \\
\hline \multirow[t]{3}{*}{ Glucose, $\mathrm{mmol} / \mathrm{L}$} & 1 to 3 & 3.87 & 3.90 & 3.55 & 3.43 & 3.30 & 0.076 & $<0.001$ & $<0.01$ & $<0.001$ & 0.14 \\
\hline & 4 to 6 & 3.91 & 4.11 & 3.73 & 3.78 & 3.63 & 0.068 & $<0.001$ & 0.68 & $<0.001$ & $<0.001$ \\
\hline & 7 to 12 & 4.05 & 4.16 & 4.02 & 4.03 & 3.96 & 0.064 & 0.11 & 0.64 & 0.01 & 0.05 \\
\hline \multirow{3}{*}{ NEFA, mmol/L } & 1 to 3 & 0.89 & 0.87 & 1.14 & 1.30 & 1.25 & 0.070 & $<0.001$ & $<0.05$ & $<0.001$ & 0.75 \\
\hline & 4 to 6 & 0.86 & 0.71 & 0.89 & 0.93 & 0.97 & 0.061 & $<0.05$ & 0.28 & $<0.001$ & $<0.05$ \\
\hline & 7 to 12 & 0.49 & 0.50 & 0.50 & 0.53 & 0.53 & 0.050 & 0.94 & 0.44 & 0.30 & 0.91 \\
\hline \multirow[t]{3}{*}{$\log _{10} \mathrm{GH}, \mathrm{ng} / \mathrm{mL}$} & 1 to 3 & $0.25(1.80)$ & $0.19(1.55)$ & $0.24(1.73)$ & $0.31(2.05)$ & $0.31(2.06)$ & 0.041 & 0.68 & 0.04 & $<0.01$ & 0.25 \\
\hline & 4 to 6 & $0.22(1.65)$ & $0.18(1.50)$ & $0.22(1.68)$ & $0.25(1.77)$ & $0.32(2.07)$ & 0.041 & 0.48 & 0.11 & $<0.01$ & 0.07 \\
\hline & 7 to 12 & $0.28(1.89)$ & $0.25(1.76)$ & $0.30(2.02)$ & $0.28(1.88)$ & $0.30(2.00)$ & 0.033 & 0.13 & 0.57 & 0.24 & 0.23 \\
\hline \multirow[t]{3}{*}{$\log _{10}$ IGF-I, ng/mL } & 1 to 3 & $0.87(7.44)$ & $0.90(7.91)$ & $0.84(6.89)$ & $0.86(7.18)$ & $0.85(7.14)$ & 0.029 & 0.06 & 0.50 & 0.14 & 0.47 \\
\hline & 4 to 6 & $0.92(8.26)$ & $0.96(9.11)$ & $0.91(8.05)$ & $0.87(7.45)$ & $0.82(6.64)$ & 0.029 & 0.19 & 0.02 & $<0.001$ & 0.02 \\
\hline & 7 to 12 & $1.03(10.64)$ & $1.05(11.13)$ & $1.02(10.40)$ & $0.97(9.35)$ & $0.93(8.55)$ & 0.034 & 0.50 & 0.02 & $<0.001$ & 0.23 \\
\hline \multirow[t]{3}{*}{$\log _{10}$ insulin, $\mu \mathrm{U} / \mathrm{mL}$} & 1 to 3 & $0.43(2.68)$ & $0.37(2.34)$ & $0.21(1.62)$ & $0.19(1.56)$ & $0.16(1.44)$ & 0.037 & $<0.001$ & 0.30 & $<0.001$ & 0.65 \\
\hline & 4 to 6 & $0.34(2.18)$ & $0.40(2.49)$ & $0.27(1.85)$ & $0.27(1.85)$ & $0.22(1.66)$ & 0.037 & $<0.001$ & 0.43 & $<0.001$ & 0.05 \\
\hline & 7 to 12 & $0.43(2.72)$ & $0.43(2.68)$ & $0.38(2.38)$ & $0.36(2.30)$ & $0.36(2.30)$ & 0.033 & 0.06 & 0.63 & $<0.01$ & 0.90 \\
\hline \multirow[t]{3}{*}{$\log _{10}$ AST, U/L } & 1 to 3 & $1.83(67.3)$ & $1.84(68.9)$ & $1.85(70.2)$ & $1.86(72.9)$ & $1.88(75.8)$ & 0.022 & 0.48 & 0.19 & 0.01 & 0.84 \\
\hline & 4 to 6 & $1.82(66.4)$ & $1.80(63.0)$ & $1.82(65.9)$ & $1.85(71.5)$ & $1.89(77.8)$ & 0.025 & 0.70 & 0.01 & $<0.001$ & 0.09 \\
\hline & 7 to 12 & $1.81(63.9)$ & $1.81(64.9)$ & $1.79(62.2)$ & $1.82(66.4)$ & $1.84(69.3)$ & 0.020 & 0.38 & $<0.05$ & 0.10 & 0.67 \\
\hline \multirow[t]{3}{*}{$\log _{10} \mathrm{GDH}, \mathrm{U} / \mathrm{L}$} & 1 to 3 & $1.20(16.0)$ & $1.18(15.0)$ & $1.29(19.6)$ & $1.34(21.8)$ & $1.33(21.6)$ & 0.076 & 0.12 & 0.52 & $<0.01$ & 0.81 \\
\hline & 4 to 6 & $1.35(22.3)$ & $1.28(19.1)$ & $1.40(25.2)$ & $1.49(30.9)$ & $1.52(32.9)$ & 0.087 & 0.25 & 0.17 & $<0.01$ & 0.44 \\
\hline & 7 to 12 & $1.34(22.0)$ & $1.31(20.3)$ & $1.37(23.4)$ & $1.41(25.5)$ & $1.39(24.7)$ & 0.069 & 0.45 & 0.62 & 0.13 & 0.83 \\
\hline
\end{tabular}

Dormone and liver enzyme concentrations were logarithmically transformed before statistical analysis; values in parentheses represent back-transformed means.

$\stackrel{2}{2} \mathrm{GH}=$ growth hormone; AST = aspartate aminotransferase; GDH = glutamate dehydrogenase.

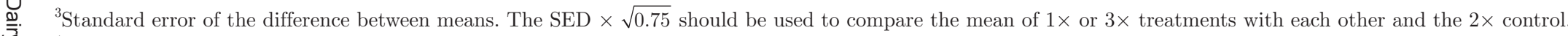

${ }^{4}$ Milking frequency $(1 \times, 2 \times$, or $3 \times)$ by duration (3 or 6 wk) interaction. 
and 8 , after cows milked $1 \times$ for 6 wk postpartum were changed to $2 \times$ milking (Figure $2 \mathrm{~A}$ ). This 2 -wk carryover response was similar to that reported for housed cows by Loiselle et al. (2009), although this effect is not always apparent (McNamara et al., 2008; Schlamberger et al., 2010). Loiselle et al. (2009) and Schlamberger et al. (2010) also reported that reduced plasma NEFA concentrations persisted for approximately 2 to 3 wk after housed cows were milked $1 \times$ for 1 and 4 wk postpartum, respectively. In the present study, no residual effect was detected of reduced postpartum MF on plasma NEFA concentration in grazing cows (Figure 2B; Table 4), as reported previously (Kay et al., 2013). Hence, metabolic profiles indicated that improvements in energy status from temporarily milking cows $1 \times$ following calving occurred during the period of less frequent milking, but these effects did not last long when cows were switched to $2 \times$ milking.

In contrast, the effects of $3 \times$ milking on blood metabolic indicators of energy status occurred primarily during the first 3 wk of lactation. Plasma concentrations of glucose and NEFA from wk 4 onwards were similar between cows milked $3 \times$ or $2 \times$, regardless of the duration of increased MF postpartum. This response concurs with the lack of a duration effect on the milk yield increase from $3 \times$ milking, and indicates that the grazing cows initially responded to the stimulatory effect of increased MF by mobilizing more body fat during the first week of lactation to provide energy for greater milk production. Indeed, cows milked $3 \times$ had a greater $(P<0.05)$ BCS loss during wk 1 postpartum than cows milked $2 \times(+0.20 \mathrm{U}$; Figure $3 \mathrm{~A})$, and tended to have a lower BCS at wk 2 and 3 postpartum $[-0.16$ $\mathrm{U}(P=0.09)$ and $-0.18 \mathrm{U}(P=0.06)$, respectively; Figure $3 \mathrm{~A}]$; however, no differences in BCS were detected thereafter. Body weight did not differ, at any stage of lactation, between cows milked $3 \times$ postpartum or $2 \times$ (Figure 2B). Therefore, this greater body fat mobilization was not sustained in cows genetically selected for pasture-based systems, perhaps as a protective mechanism against excessive BCS loss during early lactation, which is undesirable to maintain an annual, seasonally concentrated breeding cycle. This effect may explain the relatively small increases in milk yield and the lack of increases in milk component yields, and indicates that extra energy than was offered must be supplied to achieve better production responses to increased $\mathrm{MF}$ (Andersen et al., 2003; Yeo et al., 2003).

The altered plasma glucose and NEFA profiles in cows milked $1 \times$ during early lactation indicated lower requirements by the mammary gland for energy and precursors for milk production. Greater circulating glucose concentrations in cows milked $1 \times$ relative to $2 \times$ most likely occurred because of reduced mammary gland uptake of glucose for lactose synthesis and, consequently, milk production (Guinard-Flament et al., 2006). Furthermore, the reduction in circulating NEFA concentrations in cows milked $1 \times$ was consistent with a reduced energy demand by the mammary gland, which limited the amount of body fat mobilized for milk production and, therefore, improved energy status.

In support of this conclusion, the BCS profiles of cows milked $1 \times$ postpartum gradually diverged from those of cows milked $2 \times$ (Figure 3A), with BCS tending to be greater at wk $5(+0.15 \mathrm{U} ; P=0.10)$ and was greater at wk 6 and $8(+0.23 \mathrm{U} ; P<0.05)$ for cows milked $1 \times$ postpartum. A trend $(P=0.07)$ for a $\mathrm{MF} \times$ duration interaction at wk 6 indicated that the increase in BCS tended to be greater when cows were milked $1 \times$ for 6 wk compared with $3 \mathrm{wk}(+0.30$ vs. $+0.16 \mathrm{U}$, respectively); however, no interactions existed at wk 8. Mean BCS during wk 8 to 32 of lactation tended to remain greater $(+0.14 \mathrm{U} ; P=0.09)$ in cows milked $1 \times$ postpartum, but no difference $(P=0.51)$ existed in late lactation (wk 32).

Body weight was also increased by milking cows $1 \times$ for a short period at the beginning of lactation (Figure $3 \mathrm{~B})$. Cows milked $1 \times$ postpartum had a greater BW at wk $4(+13.5 \mathrm{~kg} ; P<0.05)$, and tended to have a greater BW at wk 5 and 6 , than cows milked $2 \times[+8.8(P=$ $0.10)$ and $+10.0 \mathrm{~kg}(P=0.05)$, respectively]. Mean BW during wk 8 to 32 was also greater $(+11.9 \mathrm{~kg} ; P<0.01)$ in cows milked $1 \times$ postpartum. However, interactions between MF and duration at wk $6(P=0.03)$ and during wk 8 to $32(P=0.10)$ indicated that the effect of $1 \times$ milking on $\mathrm{BW}$ was dependent on its duration.

Improvements in BCS and BW from milking $1 \times$ for a short period (3 to $6 \mathrm{wk}$ ) were reported previously (Rémond et al., 1999; McNamara et al., 2008; Schlamberger et al., 2010); these differences remained, at least in part, when cows were switched to $2 \times$ milking. In addition, Rémond et al. (1999) reported that longer durations of $1 \times$ milking postpartum resulted in greater improvements in BW and, to a lesser extent, BCS, supporting the results of the present study. The occurrence of much greater BW and BCS by dry-off when cows are milked $1 \times$ relative to $2 \times$ for the entire lactation (Clark et al., 2006) is consistent with an increasing effect of $1 \times$ milking on these parameters with longer durations of reduced MF.

The effects of postpartum MF on cow metabolic status, BCS, and BW may be mediated through an altered degree of uncoupling of the somatotropic axis during early lactation. High GH and low IGF-I concentrations in blood are characteristic of an uncoupled somatotropic axis in the postparturient dairy cow, and along with a state of hypoinsulinemia, modify metabolism to support the rapid, massive increase in nutrients 
required by the mammary gland for milk production (Bauman, 2000; Butler et al., 2003). Indeed, consistent with their greater milk production, cows milked $3 \times$ had greater mean plasma concentrations of GH during wk 1 to 3 relative to cows milked $2 \times$ or $1 \times$, and a trend $(P=0.07)$ for a $\mathrm{MF} \times$ duration interaction during wk 4 to 6 indicated that this effect continued for cows that remained on $3 \times$ milking for $6 \mathrm{wk}(P<0.05$; Table 4; Figure 4A). Furthermore, although no differences in IGF-I concentrations existed during wk 1 to 3 postpartum between cows milked $3 \times$ and $2 \times$, both treatment groups had lower $(P<0.01)$ IGF-I at wk 3 relative to cows milked $1 \times$ (Table 4 ; Figure $4 \mathrm{~B}$ ). During wk 4 to 6 , the $3 \times$ cows had lower IGF- 1 than $2 \times$ or $1 \times$ cows, but these differences were greatest for cows still on differential MF treatments (Table 4; Figure 4B). Therefore, GH and IGF-1 profiles indicate that a greater level of somatotropic axis uncoupling occurred during the first 6 wk of lactation with increasing MF, which is due to downregulation of the hepatic mRNA expression of GH receptors and reduced negative feedback on GH secretion from the pituitary gland (Lucy et al., 2001, 2009). This conclusion is supported by a companion study by Grala et al. (2013), which detected lower GH receptor and IGF-I expression in liver biopsies from cows milked $3 \times$. Furthermore, these effects could be regulated by altered plasma insulin concentrations in response to postpartum MF (Table 4; Figure 4C).

Insulin is a key signal mediating the recoupling of the somatotropic axis by stimulating hepatic GH receptor transcription (Butler et al., 2003), and it was greater in blood from cows milked less frequently during early lactation in response to their greater circulating concentrations of glucose (Table 5). Cows milked $1 \times$ had greater plasma insulin during wk 1 to 3 postpartum compared with those milked $2 \times$ or $3 \times$, and this effect continued during wk 4 to 6 postpartum, particularly for cows milked $1 \times$ for 6 wk (Table 4; Figure 4C); this result agrees with previous studies (Patton et al., 2006; McNamara et al., 2008). Together, the homeorhetic changes in plasma GH, IGF-I, and insulin concentrations would limit the amount of glucose taken up by nonmammary tissues (e.g., adipose and muscle) while promoting body fat mobilization to provide nutrients for increasing milk production with increasing postpartum MF. These effects, however, were largely confined to the first 6 wk of lactation, as although IGF-I differed $(P<0.05)$ and insulin tended to differ $(P<0.10)$ to wk 10 between cows previously milked $1 \times$ and $3 \times$, GH concentrations were similar from wk 7 onwards, irrespective of postpartum MF (Table 4; Figure 4A).

Alterations in the degree of metabolic imbalance during early lactation due to postpartum MF also affected animal health status, as indicated by different temporal profiles of plasma concentrations of the liver enzymes AST and GDH (Table 4; Figure 5A and B). Cows milked $3 \times$ had greater $(P<0.01)$ mean concentrations of these enzymes during wk 1 to 6 compared with cows milked $1 \times$. Mean AST concentration was also greater during wk 4 to 6 relative to cows milked $2 \times$, but differences were greatest between cows still remaining on differential MF treatments. At wk 7, plasma GDH concentration still differed between cows previously milked $3 \times$ relative to $1 \times$, but no treatment effects existed thereafter. In contrast, cows previously milked $3 \times$ continued to have slightly greater mean AST concentrations during wk 7 to 12 relative to those milked previously $1 \times(P=0.10)$, but now also had significantly greater mean AST concentrations relative to those previously milked $2 \times$. Elevation of these hepatic enzymes in blood with increasing MF indicates that milking cows $3 \times$ caused a greater degree of metabolic stress and hepatic lipidosis in early-lactating dairy cows (Bobe et al., 2004), whereas milking cows $1 \times$ conferred some protection against this metabolic disorder. This is not surprising given that hepatic lipidosis, also known as fatty liver syndrome, occurs when cows mobilize large amounts of body fat. The liver becomes infiltrated with large quantities of triglyceride because uptake of NEFA from blood exceeds $\beta$-oxidation and triglyceride secretion, with the condition closely associated with ketosis and decreased health, productivity, and reproductive performance (Bobe et al., 2004). Liver triglyceride quantities were not measured in the present study, but the differing plasma AST, GDH, and NEFA profiles, combined with BCS loss, indicates that animal health status decreased with increasing postpartum MF. Nevertheless, it is unclear if a poorer health status contributed to the relatively poor production response in cows milked $3 \times$ for a short duration postpartum.

The positive effects of reduced postpartum MF on the metabolic energy status and BCS of grazing cows were not, however, reflected by an improvement in cow fertility or herd reproduction parameters. Cows milked $1 \times$ postpartum did not have a shorter PPAI or greater 3 -wk submission and first-service conception rates compared with those milked $2 \times$ or $3 \times$ (Table 5 ). Considering the putative positive effect of energy balance on reproduction, these results were surprising, but may simply reflect insufficient cow numbers to detect differences in binomial reproductive data, such as submission and conception rates.

Beam and Butler (1999) reported that a shorter interval to negative energy balance nadir and an improved energy balance during wk 1 to 3 postpartum, as was evident in cows milked $1 \times$ in the present study, reduced the interval to first ovulation following calving. Furthermore, increased plasma glucose concentra- 

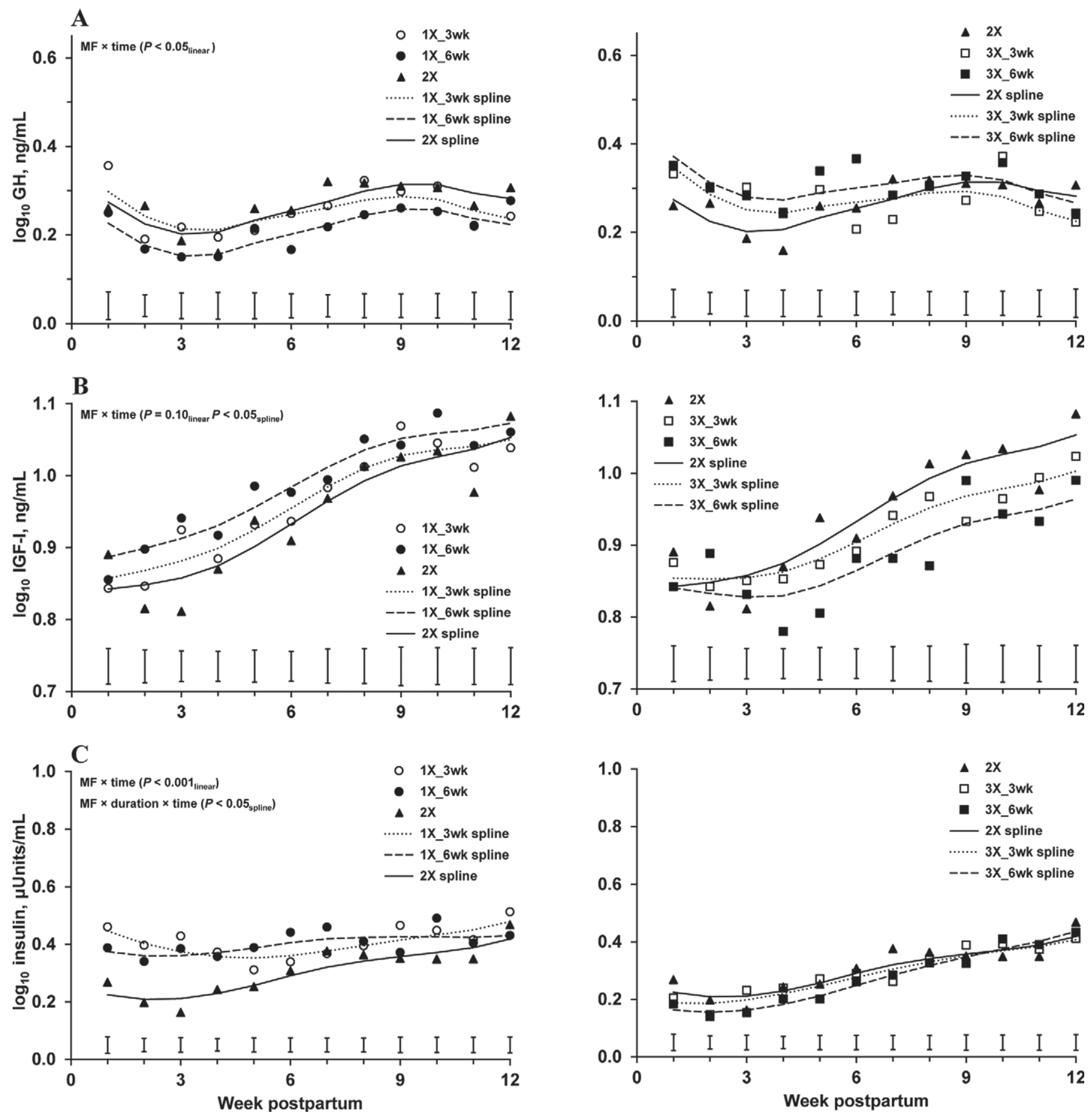

Figure 4. Plasma concentrations (weekly means and fitted splines) of (A) growth hormone (GH), (B) IGF-I, and (C) insulin during early lactation in cows milked twice daily $\left(2 \times\right.$; control), once daily $(1 \times)$ for 3 or 6 wk postpartum and $2 \times$ thereafter $\left(1 \times \_3 w k\right.$ and $1 \times \_6$ wk, respectively), or 3 times daily $(3 \times)$ for 3 or 6 wk postpartum and $2 \times$ thereafter $\left(3 \times \_3 w k\right.$ and $3 \times \_6 w k$, respectively). Logarithmically transformed mean values with the SE of the difference between means are presented. For clarity, $1 \times$ and $3 \times$ treatments are presented on separate figures with the $2 \times$ control. $P$-values for the fitted slopes are presented only if significant $(P<0.05)$ or a trend $(P \leq 0.12)$. MF $\times$ time $=$ interaction between milking frequency $(1 \times, 2 \times$, or $3 \times)$ and time; MF $\times$ duration $\times$ time $=$ interaction between milking frequency $(1 \times, 2 \times$, or $3 \times)$, duration (3 or $6 \mathrm{wk}$ ) and time. 
Table 5. Reproductive performance of pasture-based cows milked twice daily $(2 \times$; control), once daily $(1 \times)$ for 3 or 6 wk immediately postpartum and $2 \times$ thereafter, or 3 times daily $(3 \times)$ for 3 or 6 wk immediately postpartum and $2 \times$ thereafter $^{1}$

\begin{tabular}{|c|c|c|c|c|c|c|c|}
\hline Variable & \multicolumn{3}{|c|}{ Treatment } & $\mathrm{SED}^{2}$ & \multicolumn{3}{|c|}{$P$-value } \\
\hline 3 -wk submission rate, $\%$ & 85 & 93 & 85 & 7.4 & 0.23 & 0.23 & 1.00 \\
\hline First-service conception rate, $\%$ & 53 & 57 & 47 & 11.1 & 0.76 & 0.37 & 0.46 \\
\hline Final pregnancy rate, $\%$ & 95 & 90 & 84 & 6.6 & 0.38 & 0.38 & $<0.05$ \\
\hline
\end{tabular}

${ }^{1}$ Estimated postpartum anestrous intervals (PPAI) were logarithmically transformed before statistical analysis; values in parentheses represent back-transformed means. No interactions $(P>0.10)$ existed between milking frequency $(1 \times, 2 \times$, or $3 \times)$ and duration $(3$ or 6 wk $)$ for any of the variables measured; hence, only the main effects of milking frequency are presented

${ }^{2}$ Standard error of the difference between means.

tions during the early postpartum period promote the onset of cyclicity (Diskin et al., 2003) and a reduced early-lactation BCS loss is associated with a greater probability of conception to first service or a reduced interval to conception (Roche et al., 2007, 2009). Hence, the improved energy status and BCS of cows milked $1 \times$ for 3 or 6 wk postpartum in the present study may not be sufficient to exert these reproductive
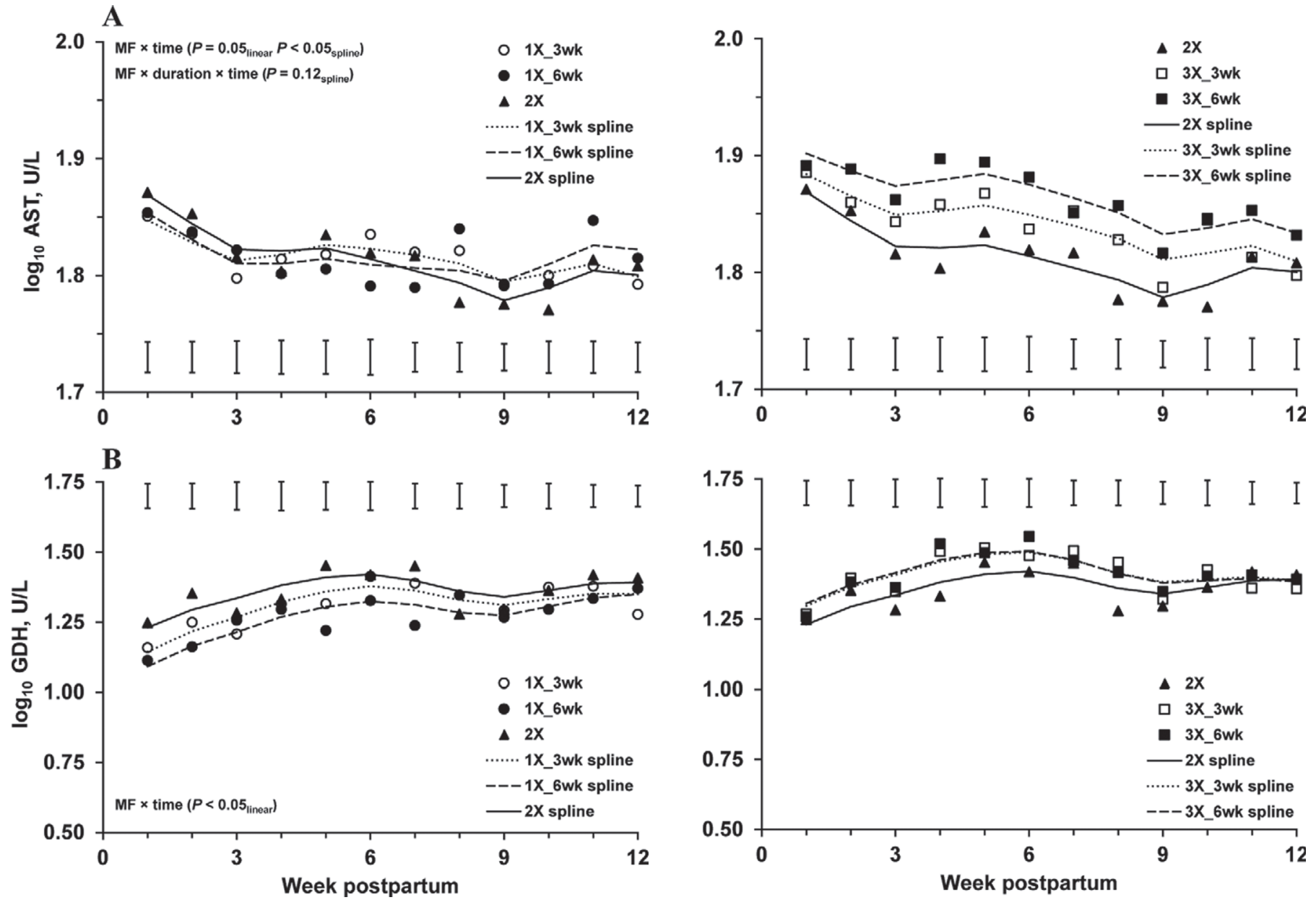

Figure 5. Plasma concentrations (weekly means and fitted splines) of (A) aspartate aminotransferase (AST) and (B) glutamate dehydrogenase $(\mathrm{GDH})$ during early lactation in cows milked twice daily $(2 \times$; control), once daily $(1 \times)$ for 3 or 6 wk postpartum and $2 \times$ thereafter $\left(1 \times \_3\right.$ wk and $1 \times \_6$ wk, respectively), or 3 times daily $(3 \times)$ for 3 or 6 wk postpartum and $2 \times$ thereafter $\left(3 \times \_3 w k\right.$ and $3 \times \_6 w k$, respectively). Logarithmically transformed mean values with the SE of the difference between means are presented. For clarity, $1 \times$ and $3 \times$ treatments are presented on separate figures with the $2 \times$ control. $P$-values for the fitted slopes are presented only if significant $(P<0.05)$ or a trend $(P \leq 0.12)$. $\mathrm{MF} \times$ time $=$ interaction between milking frequency $(1 \times, 2 \times$, or $3 \times)$ and time; $\mathrm{MF} \times$ duration $\times$ time $=$ interaction between milking frequency $(1 \times, 2 \times$, or $3 \times)$, duration ( 3 or $6 \mathrm{wk}$ ) and time. 
benefits. Conversely, the poorer energy status induced by $3 \times$ milking was perhaps not long enough or large enough to negatively affect cow fertility relative to $2 \times$ milking. These results are supported by McNamara et al. (2008), who were not able to detect a direct relationship between postpartum MF $(1 \times$ vs. $2 \times$ vs. $3 \times)$ and fertility. Nevertheless, the greater $(+11 \%)$ final pregnancy rates in cows milked $1 \times$ relative to $3 \times$ (Table 5 ) indicates that further experiments with larger numbers of cows are required to investigate whether $1 \times$ milking can be used as a strategy to improve reproductive parameters in commercial herds, particularly in cows with low fertility status and under situations of strong nutritional stress.

\section{CONCLUSIONS}

In summary, temporarily altering postpartum MF affected whole-lactation milk production and the energy status of pasture-grazed dairy cows. Milking cows $1 \times$ for 3 or $6 \mathrm{wk}$, immediately postpartum, caused similar, sustained decreases in milk and milk component yields for the rest of lactation; however, the reduced energy output in milk improved cow metabolic and energetic status, primarily for the duration of the reduced postpartum MF. In contrast, temporary $3 \times$ milking increased milk volume yields but did not result in short- or long-term increases in milk fat and protein yields, irrespective of how long cows were milked more frequently. An increased MF also induced a greater metabolic imbalance in grazing cows. Greater body fat mobilization occurred immediately postpartum, but this effect was not sustained, perhaps as a protective mechanism against excessive BCS loss. Pasture-based cows milked $3 \times$ postpartum may, therefore, require more energy-dense diets to provide sufficient nutrients for increased milk and milk component synthesis. Nonetheless, producers considering using short-term $1 \times$ milking can compare the milk production losses from this strategy to its benefits, such as improved cow energy status and BCS, reduced labor requirements, and a more flexible lifestyle, particularly during seasonal calving in pasture-based systems.

\section{ACKNOWLEDGMENTS}

The authors gratefully acknowledge the contribution and dedication of the DairyNZ Lye Farm (Hamilton, New Zealand) technical and farm teams, especially A. Napper and B. Sugar, for implementation of the experiment, and B. Dow for statistical analysis. This study was funded by New Zealand dairy farmers through DairyNZ Inc. and by the New Zealand Ministry of
Business, Innovation and Employment (Wellington, New Zealand; contract DRCX0801).

\section{REFERENCES}

Amin, D., K. Y. Saleem, and W. A. Bashir. 1982. Titrimetric determination of chloramine- $\mathrm{T}$ and some aldoses by amplification reactions. Talanta 29:694-696.

Andersen, J. B., N. C. Friggens, K. Sejrsen, M. T. Sørensen, L. Munksgaard, and K. L. Ingvartsen. 2003. The effects of low vs. high concentrate level in the diet on performance in cows milked two or three times daily in early lactation. Livest. Prod. Sci. 81:119-128.

Auldist, M. J., and C. G. Prosser. 1998. Differential effects of shortterm once-daily milking on milk yield, milk composition and concentrations of selected blood metabolites in cows with low or high pasture intake. Proc. N.Z. Soc. Anim. Prod. 58:41-43.

Bar-Peled, U., E. Maltz, I. Bruckental, Y. Folman, Y. Kali, H. Gacitua, A. R. Lehrer, C. H. Knight, B. Robinson, H. Voet, and H. Tagari. 1995. Relationship between frequent milking or suckling in early lactation and milk production of high producing dairy cows. J. Dairy Sci. 78:2726-2736.

Barbano, D. M., J. M. Lynch, and J. R. Fleming. 1991. Direct and indirect determination of true protein content of milk by Kjeldahl analysis: Collaborative study. J. Assoc. Off. Anal. Chem. Int. 74:281-288.

Bauman, D. E. 2000. Regulation of nutrient partitioning during lactation: Homeostasis and homeorhesis revisited. Pages 311-328 in Ruminant Physiology, Digestion, Metabolism, Growth and Reproduction. Proc. 9th Intl. Symp. Rumin. Physiol. P. B. Cronje, ed. Commonwealth Agricultural Bureau International, Wallingford, UK.

Beam, S. W., and W. R. Butler. 1999. Effects of energy balance on follicular development and first ovulation in postpartum dairy cows. J. Reprod. Fertil. Suppl. 54:411-424.

Bobe, G., J. W. Young, and D. C. Beitz. 2004. Invited Review: Pathology, etiology, prevention, and treatment of fatty liver in dairy cows. J. Dairy Sci. 87:3105-3124.

Boutinaud, M., M. H. Ben Chedly, E. Delamaire, and J. GuinardFlament. 2008. Milking and feed restriction regulate transcripts of mammary epithelial cells purified from milk. J. Dairy Sci. 91:988-998.

Butler, S. T., A. L. Marr, S. H. Pelton, R. P. Radcliff, and M. C. Lucy. 2003. Insulin restores GH responsiveness during lactation-induced negative energy balance in dairy cattle: Effects on expression of IGF-I and GH receptor 1A. J. Endocrinol. 176:205-217.

Carruthers, V. R., S. R. Davis, A. M. Bryant, H. V. Henderson, C A. Morris, and P. J. A. Copeman. 1993. Response of Jersey and Friesian cows to once a day milking and prediction of response based on udder characteristics and milk composition. J. Dairy Res. 60:1-11.

Chagas, L. M., P. J. S. Gore, S. Meier, K. A. Macdonald, and G. A. Verkerk. 2007. Effect of monopropylene glycol on luteinizing hormone, metabolites, and postpartum anovulatory intervals in primiparous dairy cows. J. Dairy Sci. 90:1168-1175.

Clark, D. A., C. V. C. Phyn, M. J. Tong, S. J. Collis, and D. E. Dalley. 2006. A systems comparison of once- versus twice-daily milking of pastured dairy cows. J. Dairy Sci. 89:1854-1862.

Connor, E. E., S. Siferd, T. H. Elsasser, C. Clover, C. P. Van Tassell, T. S. Sonstegard, V. Fernandes, and A. V. Capuco. 2008. Effects of increased milking frequency on gene expression in the bovine mammary gland. BMC Genomics 9:362. http://dx.doi. org/10.1186/1471-2164-9-362.

Dahl, G. E., R. L. Wallace, R. D. Shanks, and D. Lueking. 2004. Hot topic: Effects of frequent milking in early lactation on milk yield and udder health. J. Dairy Sci. 87:882-885.

Davis, S. R., V. C. Farr, and K. Stelwagen. 1999. Regulation of yield loss and milk composition during once-daily milking: A review. Livest. Prod. Sci. 59:77-94.

Diskin, M. G., D. R. Mackey, J. F. Roche, and J. M. Sreenan. 2003. Effects of nutrition and metabolic status on circulating hormones 
and ovarian follicle development in cattle. Anim. Reprod. Sci. 78:345-370.

Downing, J. A., J. Joss, P. Connell, and R. J. Scaramuzzi. 1995. Ovulation rate and the concentrations of gonadotrophic and metabolic hormones in ewes fed lupin grain. J. Reprod. Fertil. 103:137-145.

Erdman, R. A., and M. Varner. 1995. Fixed yield response to increased milking frequency. J. Dairy Sci. 78:1199-1203.

Eslamizad, M., M. Dehghan-Banadaky, K. Rezayazdi, and M. MoradiShahrbabak. 2010. Effects of 6 times daily milking during early versus full lactation of Holstein cows on milk production and blood metabolites. J. Dairy Sci. 93:4054-4061.

Farr, V. C., K. Stelwagen, M. A. Kerr, S. R. Davis, and S. J. Eichler. 1995. Brief communication: Effect of once daily milking (ODM) on enzyme activities in the bovine mammary gland. Proc. N.Z. Soc. Anim. Prod. 55:12-13.

Gluckman, P. D., J. J. Johnson-Barrett, J. H. Butler, B. W. Edgar, and T. R. Gunn. 1983. Studies of insulin-like growth factor -I and -II by specific radioligand assays in umbilical cord blood. Clin. Endocrinol. (Oxf.) 19:405-413.

Grala, T. M., C. V. C. Phyn, J. K. Kay, A. G. Rius, M. D. Littlejohn, R. G. Snell, and J. R. Roche. 2011. Temporary alterations to milking frequency, immediately post-calving, modified the expression of genes regulating milk synthesis and apoptosis in the bovine mammary gland. Proc. N.Z. Soc. Anim. Prod. 71:3-8.

Grala, T. M., C. V. C. Phyn, J. K. Kay, A. G. Rius, M. C. Lucy, M. D. Littlejohn, R. G. Snell, and J. R. Roche. 2013. Gene expression in liver and adipose tissue is altered during and after temporary changes to postpartum milking frequency. J. Dairy Sci. 97:2701-2717.

Guinard-Flament, J., E. Delamaire, S. Lemosquet, M. Boutinaud, and Y. David. 2006. Changes in mammary uptake and metabolic fate of glucose with once-daily milking and feed restriction in dairy cows. Reprod. Nutr. Dev. 46:589-598.

Hale, S. A., A. V. Capuco, and R. A. Erdman. 2003. Milk yield and mammary growth effects due to increased milking frequency during early lactation. J. Dairy Sci. 86:2061-2071.

Hales, C. N., and P. J. Randle. 1963. Immunoassay of insulin with insulin-antibody precipitate. Biochem. J. 88:137-146.

Hillerton, J. E., C. H. Knight, A. Turvey, S. D. Wheatley, and C. W. Wilde. 1990. Milk yield and mammary function in dairy cows milked four times daily. J. Dairy Res. 57:285-294.

IDF (International Dairy Federation). 1987. Milk: Determination of fat content-Röse-Gottlieb gravimetric method (reference method). IDF Standard FIL-IDF 1C:1987. IDF, Brussels, Belgium.

Kay, J. K., C. V. C. Phyn, A. G. Rius, S. R. Morgan, T. M. Grala, and J. R. Roche. 2013. Once-daily milking during a feed deficit decreases milk production but improves energy status in early lactating grazing dairy cows. J. Dairy Sci. 96:6274-6284.

Kolver, E. S., and L. D. Muller. 1998. Performance and nutrient intake of high producing Holstein cows consuming pasture or a total mixed ration. J. Dairy Sci. 81:1403-1411.

Littlejohn, M. D., C. G. Walker, H. E. Ward, K. B. Lehnert, R. G. Snell, G. A. Verkerk, R. J. Spelman, D. A. Clark, and S. R. Davis. 2010. Effects of reduced frequency of milk removal on gene expression in the bovine mammary gland. Physiol. Genomics 41:21-32.

Loiselle, M. C., C. Ster, B. G. Talbot, X. Zhao, G. F. Wagner, Y. R. Boisclair, and P. Lacasse. 2009. Impact of postpartum milking frequency on the immune system and the blood metabolite concentration of dairy cows. J. Dairy Sci. 92:1900-1912.

Lucy, M. C., H. Jiang, and Y. Kobayashi. 2001. Changes in the somatotropic axis associated with the initiation of lactation. J. Dairy Sci. 84(E. Suppl.):E113-E119.

Lucy, M. C., G. A. Verkerk, B. E. Whyte, K. A. Macdonald, L. Burton, R. T. Cursons, J. R. Roche, and C. W. Holmes. 2009. Somatotropic axis components and nutrient partitioning in genetically diverse dairy cows managed under different feed allowances in a pasture system. J. Dairy Sci. 92:526-539.

Matsuda, M., T. Imaoka, A. J. Vomachka, G. A. Gudelsky, Z. Hou, M. Mistry, J. P. Bailey, K. M. Nieport, D. J. Walther, M. Bader, and N. D. Horseman. 2004. Serotonin regulates mammary gland development via an autocrine-paracrine loop. Dev. Cell 6:193-203.
McNamara, S., J. J. Murphy, F. P. O'Mara, M. Rath, and J. F. Mee. 2008. Effect of milking frequency in early lactation on energy metabolism, milk production and reproductive performance of dairy cows. Livest. Sci. 117:70-78.

Nørgaard, J., A. Sørensen, M. T. Sørensen, J. B. Andersen, and K. Sejrsen. 2005. Mammary cell turnover and enzyme activity in dairy cows: Effects of milking frequency and diet energy density. J. Dairy Sci. 88:975-982.

NRC. 2001. Nutrient Requirements of Dairy Cattle. 7th rev. ed. Natl. Acad. Press, Washington, DC.

Patton, J., D. A. Kenny, J. F. Mee, F. P. O'Mara, D. C. Wathes, M. Cook, and J. J. Murphy. 2006. Effect of milking frequency and diet on milk production, energy balance, and reproduction in dairy cows. J. Dairy Sci. 89:1478-1487.

Phillips, D. S. M., M. W. Woolford, and P. J. A. Copeman. 1980. The implications of milking management strategies involving variations of milking frequency in the immediate post-partum period. Proc. N.Z. Soc. Anim. Prod. 40:166-174.

Rémond, B., S. Aubailly, Y. Chilliard, D. Dupont, D. Pomiès, and M. Petit. 2002. Combined effects of once-daily milking and feeding level in the first three weeks of lactation on milk production and enzyme activities, and nutritional status, in Holstein cows. Anim. Res. 51:101-117.

Rémond, B., J.-B. Coulon, M. Nicloux, and D. Levieux. 1999. Effect of temporary once-daily milking in early lactation on milk production and nutritional status of dairy cows. Ann. Zootech. 48:341-352.

Rémond, B., and D. Pomiès. 2005. Once-daily milking of dairy cows: A review of recent French experiments. Anim. Res. 54:427-442.

Roche, J. R., D. P. Berry, and E. S. Kolver. 2006. Holstein-Friesian strain and feed effects on milk production, body weight, and body condition score profiles in grazing dairy cows. J. Dairy Sci. 89:3532-3543.

Roche, J. R., P. G. Dillon, C. R. Stockdale, L. H. Baumgard, and J. M. VanBaale. 2004. Relationships among international body condition scoring systems. J. Dairy Sci. 87:3076-3079.

Roche, J. R., N. C. Friggens, J. K. Kay, M. W. Fisher, K. J. Stafford, and D. P. Berry. 2009. Invited review: Body condition score and its association with dairy cow productivity, health, and welfare. J. Dairy Sci. 92:5769-5801.

Roche, J. R., J. K. Kay, A. G. Rius, T. M. Grala, A. J. Sheahan, H. M. White, and C. V. C. Phyn. 2013. Short communication: Immediate and deferred milk production responses to concentrate supplements in cows grazing fresh pasture. J. Dairy Sci. 96:2544-2550.

Roche, J. R., E. S. Kolver, and J. K. Kay. 2005. Influence of precalving feed allowance on periparturient metabolic and hormonal responses and milk production in grazing dairy cows. J. Dairy Sci. 88:677-689.

Roche, J. R., K. A. Macdonald, C. R. Burke, J. M. Lee, and D. P. Berry. 2007. Associations among body condition score, body weight, and reproductive performance in seasonal-caving dairy cattle. J. Dairy Sci. 90:376-391.

Roche, J. R., J. Morton, and E. S. Kolver. 2002. Sulfur and chlorine play a non-acid base role in periparturient calcium homeostasis. J. Dairy Sci. 85:3444-3453.

Schlamberger, G., S. Wiedemann, E. Viturro, H. H. D. Meyer, and M. Kaske. 2010. Effects of continuous milking during the dry period or once daily milking in the first 4 weeks of lactation on metabolism and productivity of dairy cows. J. Dairy Sci. 93:2471-2485.

Shamay, A., D. A. Shinder, I. Bruckental, and N. Silanikove. 1997. Inhibition of lactogenic activities of bovine mammary gland explants by the whey fraction of bovine milk. Cell Biol. Int. 21:601-604.

Soberon, F., J. L. Lukas, M. E. Van Amburgh, A. V. Capuco, D. M. Galton, and T. R. Overton. 2010. Effects of increased milking frequency on metabolism and mammary cell proliferation in Holstein dairy cows. J. Dairy Sci. 93:565-573.

Stelwagen, K. 2001. Effect of milking frequency on mammary functioning and shape of the lactation curve. J. Dairy Sci. 84(E. Suppl.):E204-E211.

Stelwagen, K., C. V. C. Phyn, S. R. Davis, J. Guinard-Flament, D. Pomiès, J. R. Roche, and J. K. Kay. 2013. Invited review: Reduced 
milking frequency: Milk production and management implications. J. Dairy Sci. 96:3401-3413.

Stockdale, C. R. 2006. Influence of milking frequency on the productivity of dairy cows. Aust. J. Exp. Agric. 46:965-974.

Tyrrell, H. F., and J. T. Reid. 1965. Prediction of the energy value of cow's milk. J. Dairy Sci. 48:1215-1223.

Verbyla, A. P., B. R. Cullis, M. G. Kenward, and S. J. Welham. 1999. The analysis of designed experiments and longitudinal data by using smoothing splines. Appl. Stat. 48:269-311.

Wall, E. H., J. P. Bond, and T. B. McFadden. 2012. The acute milk yield response to frequent milking during early lactation is mediated by genes transiently regulated by milk removal. Physiol. Genomics 44:25-34.

Wall, E. H., H. M. Crawford, S. E. Ellis, G. E. Dahl, and T. B. McFadden. 2006. Mammary response to exogenous prolactin or frequent milking during early lactation in dairy cows. J. Dairy Sci. 89:4640-4648.

Wall, E. H., and T. B. McFadden. 2007. Optimal timing and duration of unilateral frequent milking during early lactation of dairy cows. J. Dairy Sci. 90:5042-5048.

Wall, E. H., and T. B. McFadden. 2008. Use or lose it: Enhancing milk production efficiency by frequent milking of dairy cows. J. Anim. Sci. 86(Suppl. 1):27-36. http://dx.doi.org/10.2527/jas.2007-0318.
Wall, E. H., and T. B. McFadden. 2010. The effects of milk removal or four-times-daily milking on mammary expression of genes involved in the insulin-like growth factor-I axis. J. Dairy Sci. 93:4062-4070.

Wall, E. H., and T. B. McFadden. 2012. Triennial Lactation Symposium: A local affair: How the mammary gland adapts to changes in milking frequency. J. Anim. Sci. 90:1695-1707. http://dx.doi. org/10.2527/jas.2011-4790.

Wilde, C. J., C. V. Addey, L. M. Boddy, and M. Peaker. 1995. Autocrine regulation of milk secretion by a protein in milk. Biochem. J. 305:51-58.

Wildman, E. E., G. M. Jones, P. E. Wagner, R. L. Boman, H. F. Troutt Jr., and T. N. Lesch. 1982. A dairy cow body condition scoring system and its relationship to selected production characteristics. J. Dairy Sci. 65:495-501.

Yeo, J.-M., C. H. Knight, and D. G. Chamberlain. 2003. Effects of dietary amino acid balance on the response of dairy cows to an increase of milking frequency from twice to three times daily. J. Dairy Sci. 86:3309-3312. 